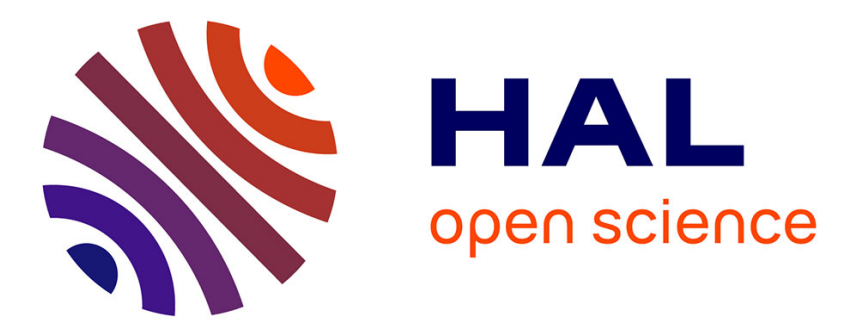

\title{
A Porphyrin Dimer-GdDOTA Conjugate as a Theranostic Agent for One- and Two-Photon Photodynamic Therapy and MRI
}

Julie Schmitt, Sébastien Jenni, Angélique Sour, Valérie Heitz, Frédéric Bolze, Agnès Pallier, Célia Bonnet, Éva Tóth, Barbara Ventura

\section{To cite this version:}

Julie Schmitt, Sébastien Jenni, Angélique Sour, Valérie Heitz, Frédéric Bolze, et al.. A Porphyrin Dimer-GdDOTA Conjugate as a Theranostic Agent for One- and Two-Photon Photodynamic Therapy and MRI. Bioconjugate Chemistry, 2018, 29 (11), pp.3726-3738. 10.1021/acs.bioconjchem.8b00634 . hal-02071234

\section{HAL Id: hal-02071234 \\ https://hal.science/hal-02071234}

Submitted on 24 Nov 2021

HAL is a multi-disciplinary open access archive for the deposit and dissemination of scientific research documents, whether they are published or not. The documents may come from teaching and research institutions in France or abroad, or from public or private research centers.
L'archive ouverte pluridisciplinaire HAL, est destinée au dépôt et à la diffusion de documents scientifiques de niveau recherche, publiés ou non, émanant des établissements d'enseignement et de recherche français ou étrangers, des laboratoires publics ou privés. 


\title{
A Porphyrin Dimer-GdDOTA Conjugate as a Theranostic Agent for One- and Two-Photon Photodynamic Therapy and MRI
}

\author{
Julie Schmitt, ${ }^{[\mathrm{a}]}$ Sébastien Jenni, ${ }^{[\mathrm{a}]}$ Angélique Sour, ${ }^{[\mathrm{a}]}$ Valérie Heitz, ${ }^{[\mathrm{a}]^{*}}$ Frédéric Bolze,,${ }^{\mathrm{b}]}{ }^{*}$ \\ Agnès Pallier, ${ }^{[\mathrm{c}]}$ Célia S. Bonnet, ${ }^{[\mathrm{c}]}$ Éva Tóth,,${ }^{[\mathrm{c}]^{*}}$ and Barbara Ventura ${ }^{[\mathrm{d}]^{*}}$
}

\begin{abstract}
[a] Laboratoire de Synthèse des Assemblages Moléculaires Multifonctionnels, Institut de Chimie de Strasbourg, CNRS/UMR 7177, Université de Strasbourg, 4, rue Blaise Pascal, 67000 Strasbourg (France). E-mail: v.heitz@unistra.fr

[b] CAMB, CNRS/UMR 7199, Faculté de Pharmacie, Université de Strasbourg, 74 route du Rhin, 67401 Illkirch (France). E-mail: frederic.bolze@unistra.fr

${ }^{[c]}$ Centre de Biophysique Moléculaire UPR4301, CNRS, Université d'Orléans, rue Charles Sadron, 45071 Orléans (France). E-mail: eva.jakabtoth@cnrs-orleans.fr

[d] Istituto ISOF-CNR, Via P. Gobetti 101, 40129 Bologna (Italy). E-mail : barbara.ventura@isof.cnr.it
\end{abstract}

\begin{abstract}
A molecular theranostic agent designed for photodynamic therapy (PDT) treatment in the near-infrared and for imaging tissue tumors with magnetic resonance imaging (MRI) is reported. It consists of a linear $\pi$-conjugated $\mathrm{Zn}(\mathrm{II})$-porphyrin dimer linked at each extremity to a GdDOTA-type complex. This agent has shown very promising potential for PDT applications with good singlet oxygen generation in DMSO and high linear absorption in the near-infrared $\left(\lambda_{\max }=746 \mathrm{~nm}, \varepsilon \approx 10^{5} \mathrm{M}^{-1} \mathrm{~cm}^{-1}\right)$. Moreover, this molecule has a propensity for two-photon excited PDT with high two-photon cross-sections $(\approx 8000 \mathrm{GM}$ in $880-930 \mathrm{~nm}$ range), which should allow for deeper tumor treatments and higher spatial precision as compared to conventional one-photon PDT. Regarding the MRI contrast agent properties, the molecule has shown superior relaxivity $\left(14.4 \mathrm{mM}^{-1} \mathrm{~s}^{-1}\right.$ at $\left.40 \mathrm{MHz}, 298 \mathrm{~K}\right)$ in comparison to clinical contrast agents and ability to be internalized in cells, thanks to its amphiphilic character. Irradiation of HeLa cells using either one-photon $(740 \mathrm{~nm})$ or two-photon excitation $(910 \mathrm{~nm})$ has led in both cases to important cell death.
\end{abstract}

\section{- Introduction}

Photodynamic therapy is an appealing therapy classified as non-invasive and intrinsically selective since a light source targeting the disease tissue is used to activate a photosensitizing drug., 2 Following light absorption, the drug will interact from its triplet excited state with surrounding oxygen via energy transfer to generate singlet oxygen or via electron transfer to generate reactive oxygen species that react with biological substrates, both processes leading to 
cell death. PDT is particularly suited to cure early-stage cancers and localized tumors. It has no long-term side effects and can be operated repeatedly without development of treatment resistance. It is therefore also used as an adjuvant therapy to chemotherapy or radiotherapy. The efficiency of PDT is strongly dependent on (i) the accessibility of the photosensitizer to light exposure and (ii) the concentration of the photosensitizer inside tumor tissues and cells. Light excitation is currently performed in the visible region where the clinically used porphyrin-based photosensitizers mainly absorb. However, irradiation performed below $700 \mathrm{~nm}$ is far from being optimal for PDT, since these photons are absorbed and scattered by living tissues and cause photodamage to healthy tissue. In addition, these phenomena induce limited tissue penetration, restricting the use of PDT to treat superficial and interstitial areas that are directly accessible by a light source. To overcome these limitations, various chromophores related to porphyrins, chlorins or expanded porphyrins with long-wavelength absorption bands in the optical therapeutic window $(700-1000 \mathrm{~nm})$ were developed ${ }^{3.6}$ Lutrin ${ }^{\circledR}$, a lutetium texaphyrin $\left(\lambda_{\max }=732 \mathrm{~nm}\right)$ has reached clinical trials ${ }^{4}$ and Redaporfin ${ }^{\circledR}$, a halogenated bacteriochlorin ${ }^{6}\left(\lambda_{\max }\right.$ $=749 \mathrm{~nm})$ and Tookad ${ }^{\circledR}$, a $\operatorname{Pd}(\mathrm{II})$ bacteriopheophorbide $7,8\left(\lambda_{\max }=746 \mathrm{~nm}\right)$ have recently been approved. An alternative and emerging strategy is to take advantage of two-photon absorption (TPA), a non-linear optical process displayed by some specific $\pi$-conjugated molecules capable of absorbing simultaneously two low energy photons. With respect to one-photon absorption, TPA occurs at the focal point of the laser thus increasing the spatial confinement of the excited photosensitizer and the 3D spatial resolution of the treatment.9 Several reports have shown promising results with TP-PDT based on molecular systems ${ }^{10}$ or on nanomaterials. ${ }^{1 /-14}$

The association of an imaging modality to PDT should optimize the PDT protocol by imaging the drug accumulation over time and assessing the outcome of the therapy. The improvement of the therapy by combination of an imaging and a therapeutic agent within one molecule corresponds to the theranostic approach and it represents a major challenge in the development of personalized medicine. ${ }^{15.17}$ The fluorescence of the PDT photosensitizer has been used to track its localization ${ }^{1820}$ but good PSs are not expected to be strong emitters since singlet emission competes with intersystem crossing and thus with singlet oxygen production. Otherwise, photobleaching, autofluorescence from the tissue and scattered photons from the light excitation beam can also lead to misleading interpretation of the detected emission and prevent quantitative evaluation of the drug concentration in the diseased tissues. ${ }^{21}$ An alternative is to associate a fluorescent agent ${ }^{22,23}$ or probes detectable in other imaging modalities to the PS..$^{24,25}$ MRI is particularly well suited to follow the PDT at every stage.$^{2.31}$ It is minimally 
invasive, uses non-ionizing radiation, provides three-dimensional anatomical images with resolution on the millimeter scale and also provides in vivo physico-chemical information of soft tissues ${ }^{32.34}$ MR image contrast relies on the water density and on the relaxation time of water protons in tissues, which is strongly affected by their environment. It is often enhanced by administration of contrast agents based on stable paramagnetic gadolinium complexes that reduce the relaxation rates of water protons in their vicinity. The chemical association of an MRI contrast agent with a PDT drug is expected to bring synergetic effects for imaging the drug localization as $(i)$ the lipophilicity of the PDT sensitizer will favor contrast agent

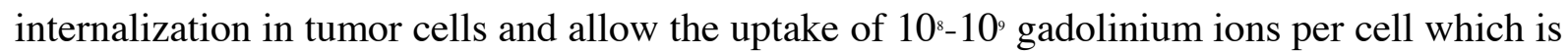
detectable on MR images, ${ }^{35}$ (ii) the increased size of the conjugate should enhance relaxivity, and (iii) the contrast enhancement in the area to be treated will be proportional to the concentration of the contrast agent-drug conjugate allowing for drug quantification.

Until now, only a few molecular systems for one-photon PDT and MRI have been evaluated as theranostic agents. ${ }^{36+7}$ In this context, we have reported a water-soluble molecular system consisting of a porphyrin linked to four gadolinium complexes [GdDTTA] (DTTA:

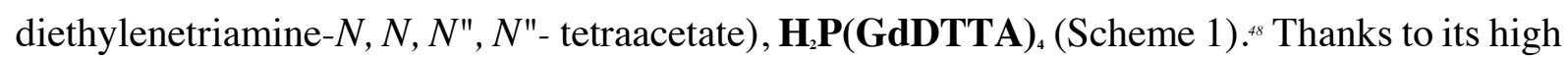
rigidity, this $\mathrm{Gd}(\mathrm{III})$-based contrast agent displays the highest relaxivity among medium-size molecular systems. Additionally, good phototoxicity results were also obtained upon visible light excitation showing the potential of this molecule as theranostic agent. To access to deeper PDT treatment while imaging with MRI, we have designed a $\pi$-delocalized porphyrindiketopyrrolopyrrole conjugate attached to a [GdDOTA] complex (DOTA: 1,4,7,10tetraazacyclododecane-1,4,7,10-tetraacetate), DPP-ZnP-GdDOTA (Scheme 1). We have demonstrated the ability of DPP-ZnP-GdDOTA to behave as a two-photon photosensitizer for PDT with excitation in the near infrared (910 nm) and as an MRI agent, even at low micromolar incubation concentration. ${ }^{49}$
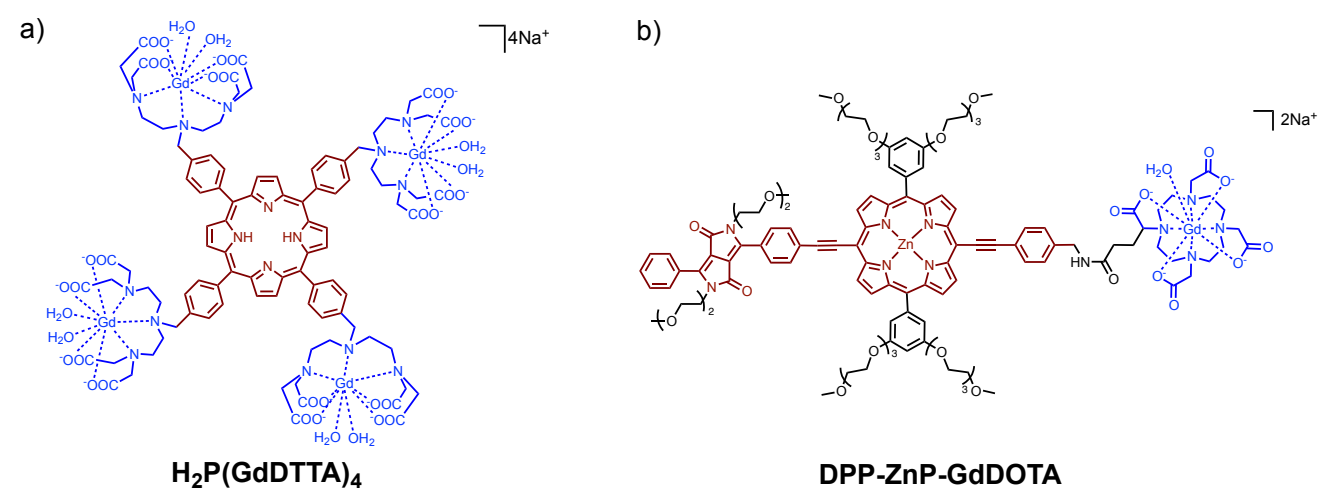
Scheme 1. Structures of two previously reported theranostic agents (a) $\mathbf{H}_{2} \mathbf{P}\left(\right.$ GdDTTA) ${ }_{4^{+8}}$ and (b) DPP-ZnP-GdDOTA ${ }^{\star 9}$.

Herein, we report a novel molecular theranostic system, 1, consisting of a linear $\pi$ conjugated Zn-porphyrin dimer linked at each extremity to a [GdDOTA]-type complex. The two Gd(III) complexes endow the conjugate with MRI detection capabilities whereas the $\mathrm{Zn}$ (II) porphyrin dimer is designed to perform efficient one- and two-photon PDT in the optical therapeutic window. The physicochemical and photophysical properties of this bifunctional agent are evaluated regarding its MR imaging and photosensitizing potential. Cellular internalization of the molecule is assessed as well as its dark toxicity and phototoxicity following one- or two-photon excitation.

\section{Q Results and discussion}

\section{Design, synthesis and characterization of the compounds.}

The chemical structures of the targeted bifunctional conjugate $\mathbf{1}$ and of the related diamagnetic conjugate 2, which incorporates [YDOTA] complexes are shown in Scheme 2. Compound 2 was prepared to optimize the final coupling step, since $\mathbf{2}$ unlike 1, can be characterized by proton NMR. The target molecule 1 consists of a central $\pi$-conjugated porphyrin dimer designed as a two-photon PDT photosensitizer with two peripheral gadolinium(III) complexes [GdDOTA] which provide the imaging capability. Hydrophilic anionic or cationic butadiynelinked Zn-porphyrin dimers developed in the group of Anderson have shown high efficiency as two-photon sensitizers for in vivo PDT..$^{50,51}$ The highly hydrophobic character of the butadiynelinked porphyrin dimer core represents a challenge for water solubilization. Therefore, two meso phenyl groups of the porphyrins were decorated with hydrophilic triethylene glycol chains. In addition, the two hydrophilic Gd(III) complexes in $\mathbf{1}$ also enhance water solubility of the final conjugate, indispensable for biological applications. The synthesis of both conjugates is based on a convergent approach and involves the coupling of the benzylic amine groups of the zinc(II)porphyrin dimer precursor $\mathbf{H}_{2} \mathbf{N}-\mathbf{Z n P - Z n P - N _ { 2 }}$ with the non-coordinating carboxylate arm of the DOTA-based complex, Na $\mathbf{a}_{2}$ [MDOTAGA] (DOTAGA : 1,4,7,10tetraazacyclododecane-1-glutaric-4,7,10-triacetate). 


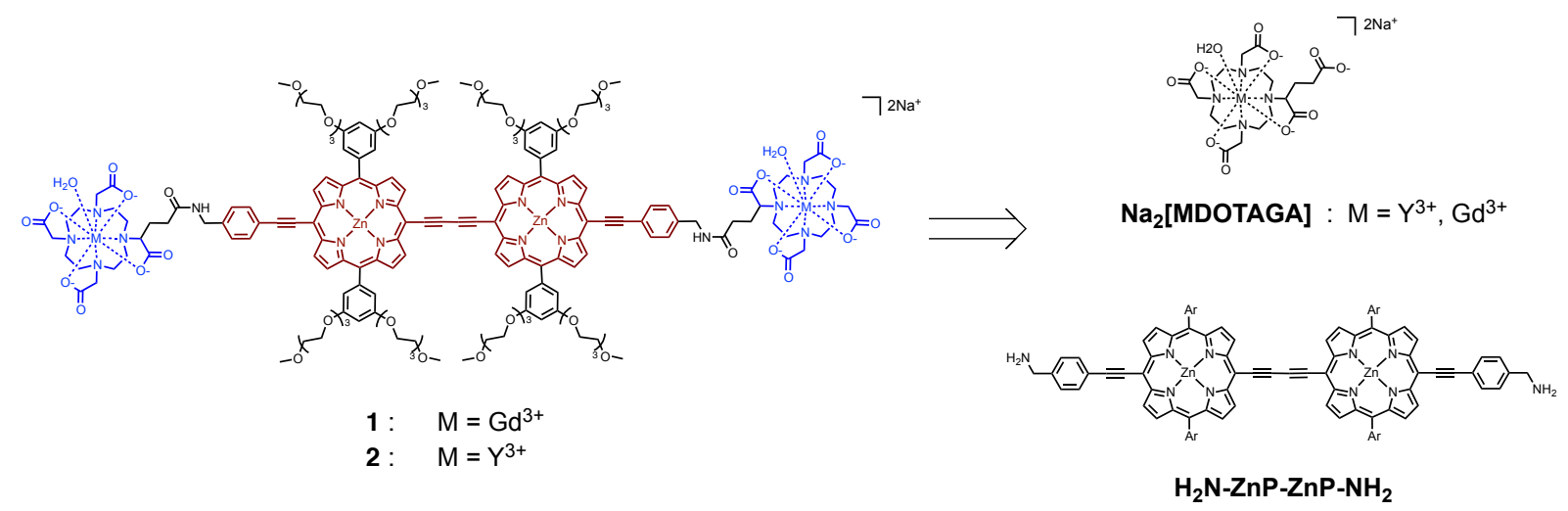

Scheme 2. Synthetic strategy used to prepare the theranostic system $\mathbf{1}$ and the related diamagnetic complex 2 .

The synthesis of the precursor $\mathbf{H}_{2} \mathbf{N}-\mathbf{Z n P}-\mathbf{Z n P}-\mathbf{N H}_{2}$ (see Scheme 3) starts from the zinc(II)porphyrin dimer TIPS-ZnP-ZnP-TIPS ${ }^{s_{2}}$ whose synthesis was inspired by a related compound reported by Anderson et al.s. After classical cleavage of the triisopropyl silyl groups using tetrabutylammonium fluoride (TBAF), the air sensitive intermediate H-ZnP-ZnP-H was submitted to Sonogashira coupling reaction with a tert-butoxycarbonyl (Boc)-protected 3iodobenzylamine. ${ }^{s t}$ BocHN-ZnP-ZnP-NHBoc was obtained in $68 \%$ yield after purification by silica gel column chromatography. Both Boc-protecting groups were then removed using trifluoroacetic acid. This reaction led to partial demetalation of the porphyrin, which was remetalated with $\mathrm{Zn}(\mathrm{OAc})_{2} .2 \mathrm{H}_{2} 0$ affording $\mathbf{H}_{2} \mathbf{N}-\mathbf{Z n P}-\mathbf{Z n P}-\mathbf{N H}_{2}$ in almost quantitative yield.

$\mathrm{Na}_{2}$ [GdDOTAGA] and its diamagnetic analogue $\mathrm{Na}_{2}$ [YDOTAGA] were readily obtained by complexation of $\mathrm{GdCl}_{3}$ and $\mathrm{YCl}_{3}$, respectively, with DOTAGA-anhydride as reported in the literature. .5 

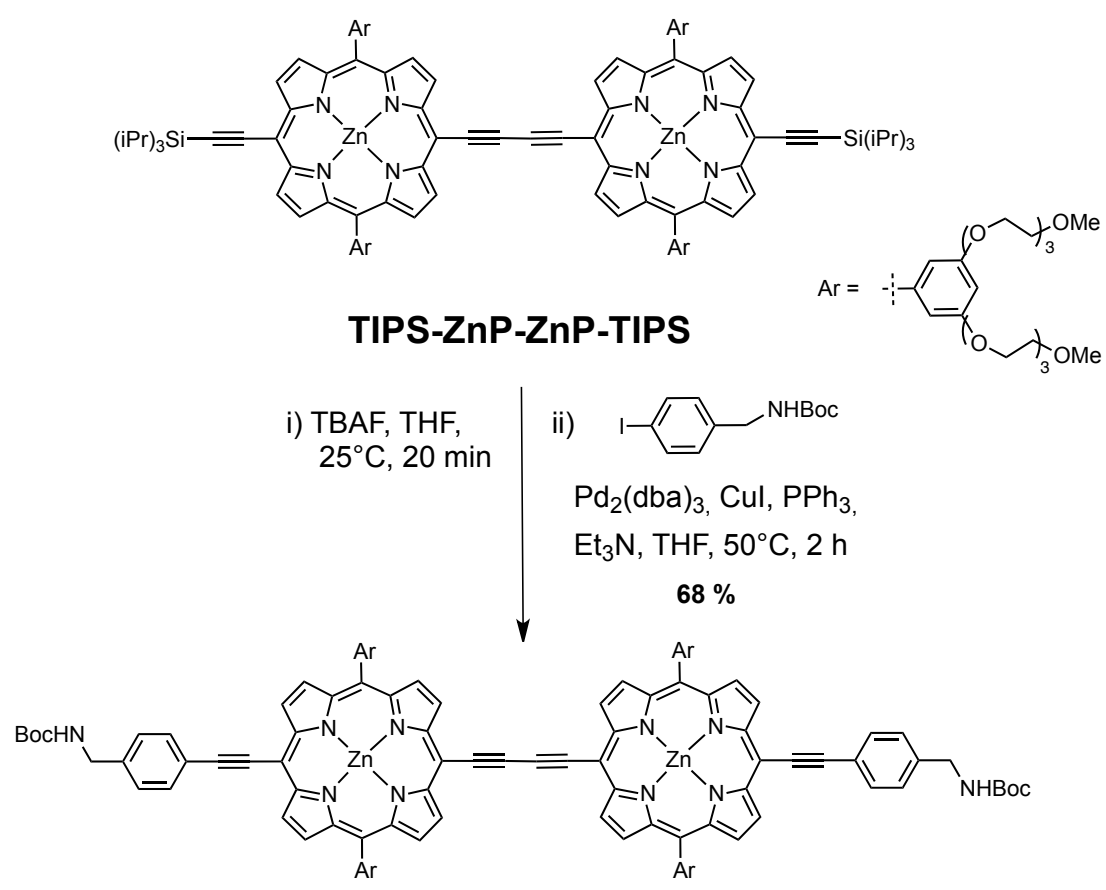

BocHN-ZnP-ZnP-NHBoc

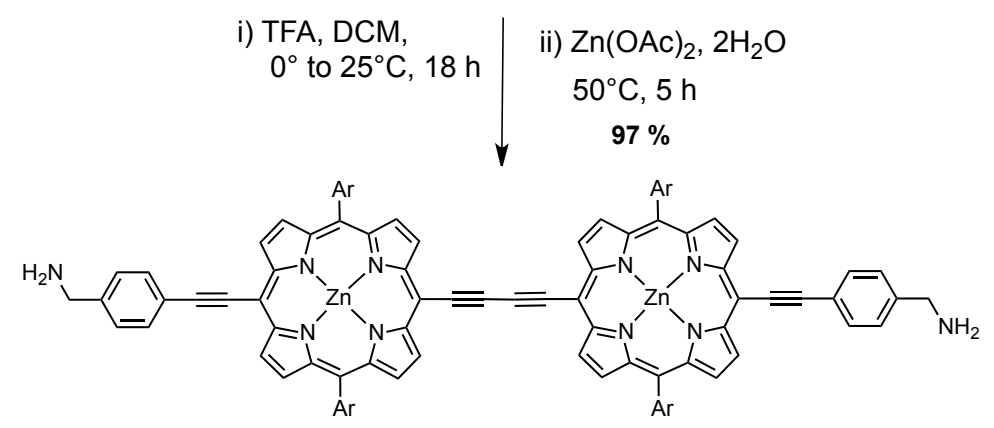

$\mathrm{H}_{2} \mathrm{~N}-\mathrm{ZnP}-\mathrm{ZnP}-\mathrm{NH}_{2}$

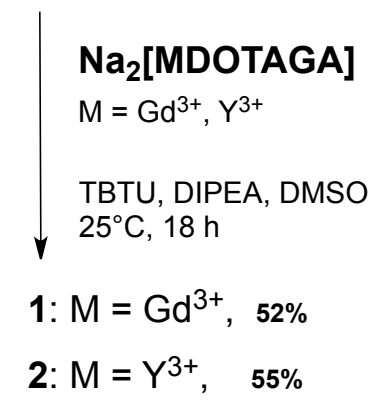

Scheme 3. Synthetic route to compounds 1 and 2.

The final hetero-tetranuclear complexes $\mathbf{1}$ and $\mathbf{2}$ were obtained by a careful choice of the amide coupling reaction conditions in order to avoid demetalation reactions. The activated ester was obtained by dissolving $\mathbf{N a}_{2}$ [MDOTAGA] in dry dimethylsulfoxyde (DMSO) at $60^{\circ} \mathrm{C}$ followed by addition of the activating agent $O$-(benzotriazol-1-yl)-N,N,N',N'-tetramethyluronium tetrafluoroborate (TBTU) and a base $N, N$-diisopropylethylamine (DIPEA). A solution of $\mathbf{H}_{2} \mathbf{N}$ - 


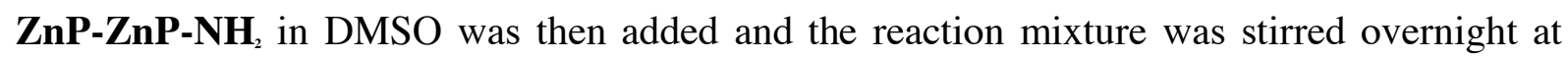
room temperature. The desired compounds $\mathbf{1}$ and $\mathbf{2}$ were isolated by precipitation after addition of dichloromethane (DCM) and thorough washing with DCM, acetone and water. Both compounds were characterized by high-resolution mass spectrometry. The isotopic profile of the molecular ionic species $\left[\mathrm{M}-2 \mathrm{H}_{2} \mathrm{O}\right]^{2} / 2$ was detected for both compounds and was in accordance with the calculated profiles (see Figures S9 and S10). Inductively coupled plasmaatomic emission spectroscopy (ICP-AES) confirmed the 1:1 ratio of $\mathrm{Gd}(\mathrm{III})$ and $\mathrm{Zn}$ (II) ions in compound 1. Compound 2 was further characterized with 1D and 2D $\mathrm{H}$ NMR spectroscopy in DMSO- $d_{6}$ (see Figures S7 and S8).

\section{Relaxivity measurements.}

The capacity of a Gd(III) complex to reduce the water proton relaxation times is expressed by its relaxivity. Relaxivity is defined as the paramagnetic enhancement of the longitudinal water proton relaxation rates and it is a direct measure of the MRI efficiency of the agent. MRI agents are typically characterized by nuclear magnetic relaxation dispersion (NMRD) profiles, which represent the magnetic field dependence of the relaxivity and therefore are useful to assess the underlying relaxation mechanisms. Relaxivity is affected by a number of microscopic parameters of the $\mathrm{Gd}(\mathrm{III})$ chelate, the most important being the hydration number $(q)$, the exchange rate of the coordinated water with the bulk $\left(k_{\mathrm{c}}\right)$, the rotational dynamics of the chelate and the parameters describing electron spin relaxation $\left(\tau \mathrm{V}\right.$ and $\left.\Delta^{2}\right)$. The relation between these parameters and relaxivity are defined by the Solomon-Bloembergen-Morgan (SBM) theory of paramagnetic relaxation.

NMRD profiles have been recorded for 1 in water containing $2 \%$ pyridine at $\mathrm{pH} 6.6$ (the presence of pyridine ensures the solubility in the $\mathrm{mM}$ range) and at two different temperatures $\left(25\right.$ and $37^{\circ} \mathrm{C}$ ) in the range of $10 \mathrm{kHz}-600 \mathrm{MHz}$ proton Larmor frequency (Figure 1 and Table S1). They have been interpreted in the frame of the SBM theory (see Supporting Information for equations and details of the fit) and the best-fit parameters are given and compared to those for analogous systems in Table 1. The hydration number was considered to be 1 , and the water exchange parameters have been fixed to the values reported for [GdDOTA] ${ }^{56}$ Data were analyzed only above $6 \mathrm{MHz}$ where the validity of the SBM theory to describe electronic relaxation and rotational dynamics of slowly rotating objects is justified. The most important information that we can obtain from this analysis concerns indeed the rotational dynamics of the conjugate. It was described in the fit with the Lipari-Szabo formalism that allows separating 
fast local and slow global motions based on the field dependency of longitudinal proton relaxation..$^{57}$ This analysis yields a local rotational correlation time, $\tau$ characterizing fast local motions of the $\mathrm{Gd}(\mathrm{III})$-water proton axis, and a global rotational correlation time, $\tau_{\mathrm{g}}$ related to the slow global motion of the system. The degree of spatial restriction of the local with respect to the global motion is expressed by the generalized, model independent order parameter $\mathrm{S}^{2}$. Indeed, the high field bump of the profiles indicate slow rotational dynamics, which is an evident consequence of the large size of the molecule. The photophysical measurements pointed to some aggregation in a $1 \%$ pyridine/water mixture. Therefore, in order to check the possible presence of aggregation phenomena, the relaxivities at $40 \mathrm{MHz}$ (and $25^{\circ} \mathrm{C}$ ) were also measured at six different concentrations covering a range of 0.1-1 mM, and they were found identical. At this frequency, the relaxivities are particularly sensitive to rotational dynamics, thus the identical values suggest that aggregation is either not important or at least does not change within this concentration range. The global rotational correlation time, $\tau_{\mathrm{g}}^{298}=1360 \mathrm{ps}$, is only slightly higher than that of the metallostar $\left\{\mathrm{Fe}\left[\mathrm{Gd} 2 \mathrm{bpy}(\mathrm{DTTA})_{2}\left(\mathrm{H}_{2} \mathrm{O}\right)_{4}\right]_{3}\right\}^{4}$ compound $\left(\tau_{\mathrm{g}}{ }^{298}=930\right.$ ps) which is a discrete molecular MRI agent of similar molecular weight, bearing six [GdDTTA] complexes around an iron(II)-tris(bipyridine) core (Scheme S1). This difference in $\tau_{\mathrm{g}}^{298}$ of 1 can be indeed ascribed to the very different topology of the two molecules (the metallostar is more spherical while $\mathbf{1}$ is more elongated with a rigid planar core). Therefore, based on the value of the global rotational correlation time, aggregation seems to remain limited under our experimental conditions.

The parameters governing the relaxivity of $\mathbf{1}$, of the metallostar and of two theranostic agents reported by us are gathered in Table 1 . In comparison to the other porphyrin-conjugated Gd(III) complexes and considering the large and rigid bis-porphyrin core of the molecule, we could expect a higher relaxivity for 1. Nevertheless, for DPP-ZnP-GdDOTA, the high relaxivity was related to a strong aggregation in aqueous solution, while for the tetramer $\mathbf{H}_{2} \mathbf{P}(\text { GdDTTA })_{4}$, the bishydrated nature of the $\mathrm{Gd}(\mathrm{III})$ chelate and a remarkable rigidity of the whole conjugate were responsible for the high relaxivity. Despite the rigid bis-porphyrin core, the two peripheral Gd(III) chelates in compound 1 experience important flexibility, as it is indicated by the low value of the generalized order parameter, $S^{2}=0.3$. This flexibility can then account for the limited increase in relaxivity, which is nevertheless around 4-fold with respect to clinically used MRI agents. Moreover, in the presence of bovine serum albumin (42.7 g.L-1), the relaxivity measured at $40 \mathrm{MHz}$ increases considerably from 14.4 to $29.7 \mathrm{mM}^{-1} \mathrm{~s}^{-1}(298 \mathrm{~K})$ or from 11.8 to $26.6 \mathrm{mM}^{-1} \mathrm{~s}^{-1}(310 \mathrm{~K})$, indicating strong albumin binding of the conjugate. The ability of our 
theranostic agent for non-covalent binding to this blood pool protein should increase its circulation time in the blood and favour its tumoral accumulation.

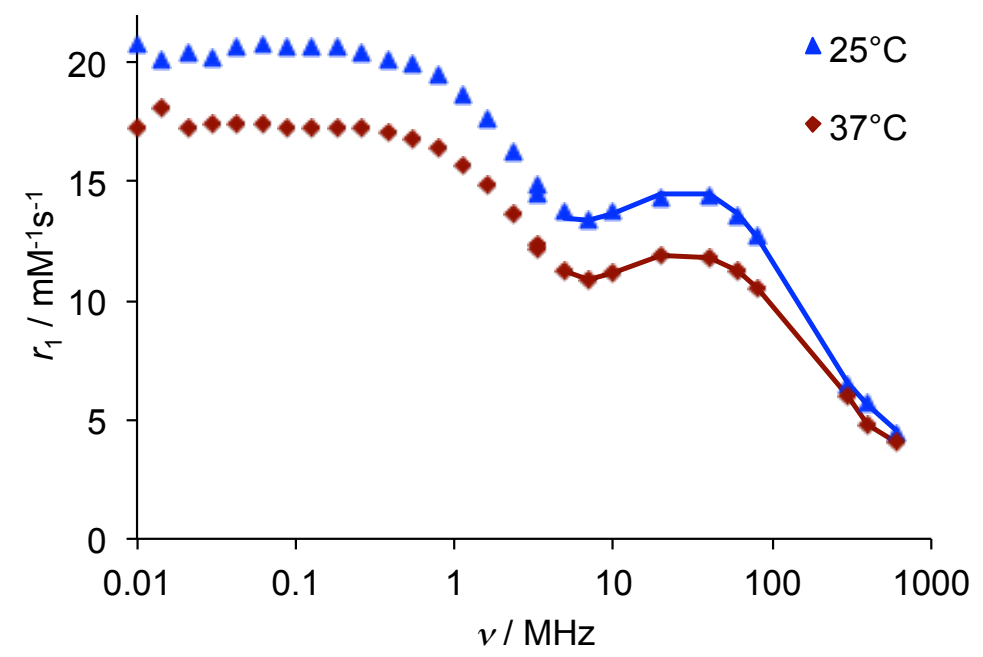

Figure 1. 'H Nuclear Magnetic Relaxation Dispersion (NMRD) profiles for $\mathbf{1}(0.81 \mathrm{mM})$ at $25^{\circ} \mathrm{C}(\boldsymbol{\Delta})$ and $37^{\circ} \mathrm{C}(\diamond)$ in $\mathrm{H}_{2} \mathrm{O}$ containing $2 \%$ pyridine, at $\mathrm{pH}$ 6.6. The continuous lines represent the fitted curves according to the SBM theory.

Table 1. Best-fit parameters obtained from the fitting of the 'H NMRD profiles to the SBM theory, including the Lipari-Szabo approach to describe internal flexibility.

\begin{tabular}{|c|c|c|c|c|}
\hline Parameters & $\begin{array}{c}\mathbf{1} \\
\text { in } \mathrm{H}_{2} \mathrm{O}+2 \% \\
\text { pyridine }\end{array}$ & $\begin{array}{c}\mathrm{H}_{2} \mathbf{P}(\text { GdDTTA })_{4} \\
\text { in } \mathrm{H}_{2} \mathrm{O}\end{array}$ & $\begin{array}{c}\text { [DPP-ZnP- } \\
\text { GdDOTA] } \\
\text { in } \mathrm{H}_{2} \mathrm{O}\end{array}$ & $\begin{array}{c}\left\{\mathbf{F e}\left[\mathbf{G d} \mathbf{d}_{2} \mathbf{b p y}(\mathbf{D T T}\right.\right. \\
\left.\left.\mathbf{A})_{2}\left(\mathbf{H}_{2} \mathbf{O}\right)_{4}\right]_{3}\right\}_{4} \text { in } \\
\mathrm{H}_{2} \mathrm{O}^{\mathrm{d}}\end{array}$ \\
\hline$M_{w}\left(\mathrm{~g} \cdot \mathrm{mol}^{-1}\right)$ & 3913 & 2761 & 2471 & 3744 \\
\hline$r_{1}\left(\mathrm{mM}^{-1} \cdot \mathrm{s}^{-1} ; 40 \mathrm{MHz}, 25^{\circ} \mathrm{C}\right)$ & 14.42 & 48.59 & 18.61 & 33.6 \\
\hline$q^{a}$ & 1 & 2 & 1 & 2 \\
\hline$k_{\mathrm{ex}}^{298}\left(10^{6} \mathrm{~s}^{-1}\right)^{\mathrm{a}}$ & 4.1 & 8.3 & 4.1 & 7.4 \\
\hline$\Delta H^{\ddagger}\left(\mathrm{kJ} \cdot \mathrm{mol}^{-1}\right)^{\mathrm{a}}$ & 49.8 & 40 & 49.8 & 41.3 \\
\hline$E_{1}\left(\mathrm{~kJ} \cdot \mathrm{mol}^{-1}\right)$ & $26 \pm 5$ & 40 & 40 & - \\
\hline$\tau_{1}^{298}(\mathrm{ps})$ & $207 \pm 14$ & 94 & 245 & 190 \\
\hline$E_{\mathrm{g}}\left(\mathrm{kJ} \cdot \mathrm{mol}^{-1}\right)$ & $25 \pm 3$ & 29 & 14 & - \\
\hline$\tau_{\mathrm{g}}^{298}(\mathrm{ps})$ & $1360 \pm 140$ & 1950 & 2640 & 930 \\
\hline$S^{2}$ & $0.30 \pm 0.03$ & 0.60 & 0.26 & 0.6 \\
\hline
\end{tabular}

${ }^{a}$ fixed in the fit; ${ }^{\mathrm{b}}$ ref ${ }^{48} ;{ }^{\mathrm{c}}$ ref ${ }^{49}$; ${ }^{\mathrm{a}}$ ref 58 


\section{One-photon photophysical characterization.}

Linear absorption, emission and singlet oxygen generation properties of compound $\mathbf{1}$ were evaluated in order to derive important parameters for both one- and two-photon PDT applications. The characterization has been performed in two polar solvents, dimethyl sulfoxide (DMSO) and $\mathrm{H}_{2} \mathrm{O}$, the latter added with $1 \%$ either of pyridine or DMSO to enhance solubility. The absorption spectra are shown in Figure 2 and relevant parameters are collected in Table 2. The spectrum in DMSO is dominated by the absorption of the porphyrin units and is red-shifted, by $20 \mathrm{~nm}$ for the Soret band and by $c a .10 \mathrm{~nm}$ for the Q-bands, with respect to that of a simpler Zn-porphyrin precursor. ${ }^{59} \mathrm{~A}$ marked splitting of the Soret band is also observed. These features can be ascribed to the extended conjugation via acetylene bridges and to excitonic interactions between the two units.60.62 The spectra in aqueous solutions are broader and less intense than in DMSO, indicating moderate aggregation phenomena.
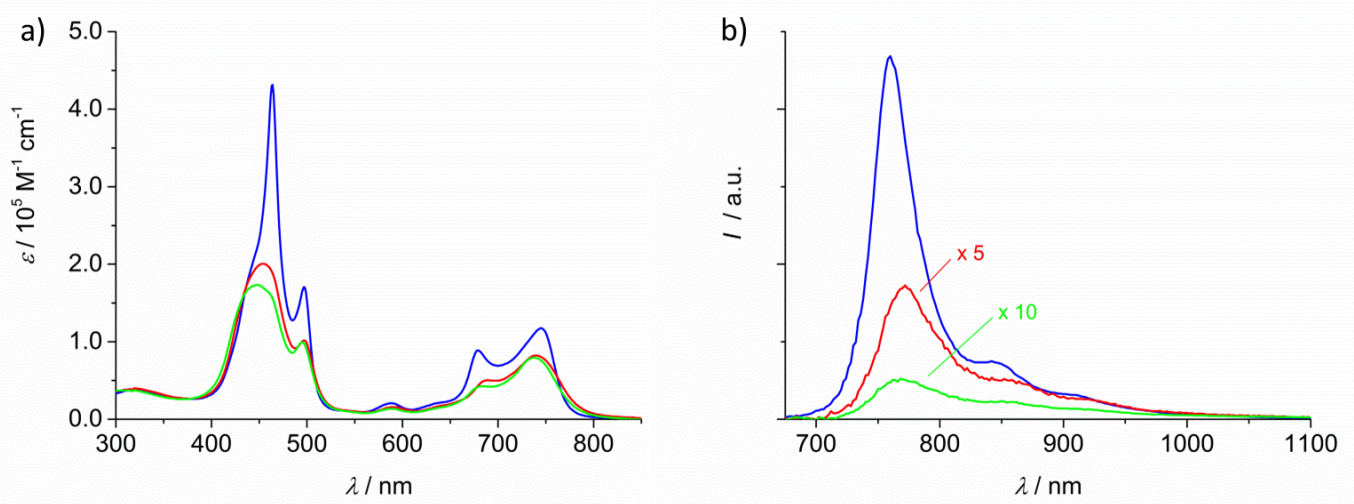

Figure 2. a) Absorption spectra of compound 1 in DMSO (blue), $\mathrm{H}_{2} \mathrm{O}$ containing $1 \%$ pyridine (red) and $\mathrm{H}_{2} \mathrm{O}$ containing $1 \%$ DMSO (green). b) Corrected emission spectra of isoabsorbing solutions of 1 in DMSO (blue), $\mathrm{H}_{2} \mathrm{O}$ containing $1 \%$ pyridine (red) and $\mathrm{H}_{2} \mathrm{O}$ containing $1 \%$ DMSO (green) at $502 \mathrm{~nm}\left(A_{502}=0.122\right)$. The red and green spectra are multiplied by a factor 5 and 10 , respectively.

Table 2. Absorption and luminescence data of compound $\mathbf{1}$ at room temperature.

\begin{tabular}{lccccc}
\hline & $\lambda_{\max +\mathrm{s}} / \mathrm{nm}\left(\varepsilon / 10^{\mathrm{s}} \mathrm{M}^{-\mathrm{cm}} \mathrm{cm}^{-1}\right)$ & $\lambda_{\max \mathrm{A}} / \mathrm{nm}^{a}$ & $\phi_{\mathrm{n}^{b}}$ & $\tau / \mathrm{ns}^{{ }^{c}}$ & $\phi_{\Delta^{d}}$ \\
\hline DMSO & $464(4.32), 497(1.71)$, & $760,842,912 \mathrm{sh}$ & 0.21 & 0.98 & 0.36 \\
& $679(0.89), 746(1.17)$ & & & & \\
$\mathrm{H}_{2} \mathrm{O}+1 \%$ pyridine & $454(2.01), 497(1.02)$, & $772,856,918 \mathrm{sh}$ & $1.9 \times 10^{2}$ & 0.99 & 0.29 \\
& $689(0.50), 740(0.82)$ & & & & 0.21 \\
$\mathrm{H}_{2} \mathrm{O}+1 \%$ DMSO & $447(1.73), 495(0.99)$, & $768,850,912 \mathrm{sh}$ & $3.2 \times 10^{3}$ & 0.82 & 0.21 \\
& $683(0.42), 738(0.80)$ & & & & \\
\hline
\end{tabular}

a From corrected emission spectra. ${ }^{b}$ Fluorescence quantum yields, measured with reference to TPP (tetra-phenyl-porphyrin) in aerated toluene as a standard. F Fluorescence lifetimes, 
excitation at $465 \mathrm{~nm} .{ }^{\triangleleft}$ Singlet oxygen production quantum yields, see the Experimental Section for details.

Fluorescence spectra of $\mathbf{1}$ in DMSO and aqueous solutions are displayed in Figure $2 \mathrm{~b}$ and the luminescence data are summarized in Table 2. The spectra extend in the near infrared and show a red shift and broadening when moving from DMSO to $\mathrm{H}_{2} \mathrm{O}$. The notable fluorescence quantum yield in DMSO (0.21) decreases from one to two orders of magnitude in aqueous solutions, to be ascribed to the existence of aggregation phenomena in aqueous environment. An estimation of the size of the aggregates was obtained from dynamic light scattering (DLS) experiments (Table S2).

Excitation spectra collected in the different solvents are in good agreement with the absorption spectra (Figure S11), confirming the nature of the observed emission. It can be noticed that the fluorescence decay of $\mathbf{1}$ in $\mathrm{H}_{2} \mathrm{O}$ is mono-exponential, with a lifetime similar to that measured in DMSO (Table 2).

Singlet oxygen production quantum yields have been measured in DMSO and aqueous solutions by means of indirect methods (see the Experimental Section for details). [Note1] A notable value of 0.36 is obtained in DMSO (Figure 3), that is very close to the $\phi_{\Delta}$ value of 0.38 obtained for the parent PS TIPS-ZnP-ZnP-TIPS ${ }^{s 2}$ and near values of 0.29 and 0.21 are measured in $\mathrm{H}_{2} \mathrm{O}$ containing $1 \%$ of pyridine and $1 \%$ of DMSO, respectively (Table 2), in accordance with moderate aggregation of $\mathbf{1}$ in the latter environments. The indirect measurement of $\phi_{\Delta}$ also evidenced the photostability of compound $\mathbf{1}$ upon irradiation in the visible range up to $21 \mathrm{~min}$ irradiation at $680 \mathrm{~nm}$ in DMSO (Figure 3) and up to $120 \mathrm{~min}$ irradiation at $516 \mathrm{~nm}$ in aqueous environments (Figure S13). The bifunctional conjugate 1 can be thus considered a promising photosensitizer for PDT applications in vivo. 
a)

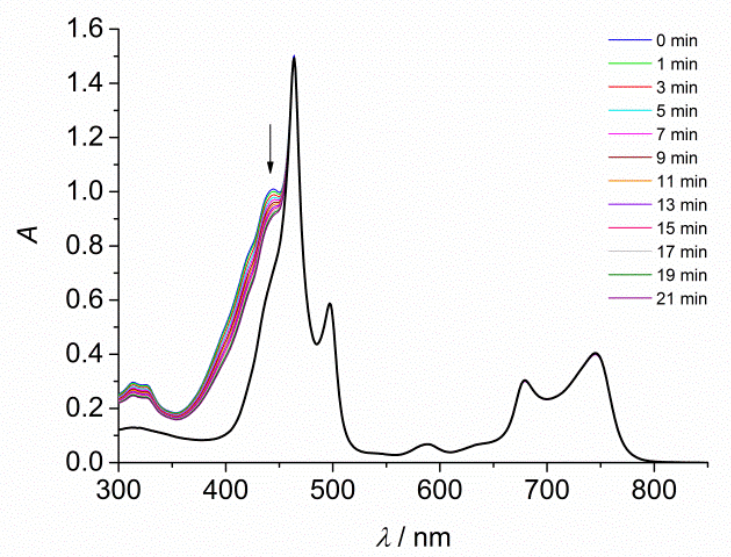

b)

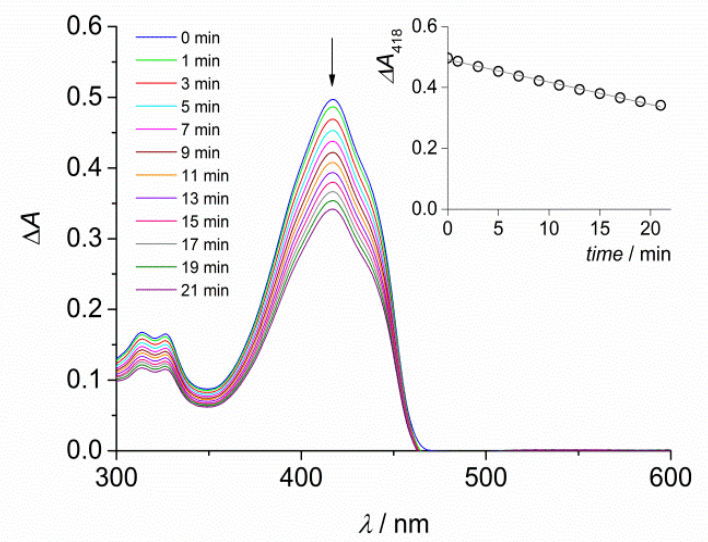

Figure 3. Singlet oxygen quantum yield determination in DMSO using 1,3diphenylisobenzofuran (DPBF) as a singlet oxygen trap. a) Absorption spectra of a DMSO solution containing $1\left(3.4 \times 10^{6} \mathrm{M}\right.$, black thick $)$ and DPBF $\left(2.2 \times 10^{s} \mathrm{M}\right)$ upon irradiation at $680 \mathrm{~nm}(0-20 \mathrm{~min})$. b) The same spectra as (a) subtracted by the contribution of compound $\mathbf{1}$. The inset shows the value of DPBF absorbance at $418 \mathrm{~nm}$ as a function of irradiation time. The same experiment for the standard $\mathrm{ZnPc}$ is reported in Figure S12.

\section{Two-photon absorption properties.}

The two-photon absorption properties of $\mathbf{1}$ were studied by the two-photon induced fluorescence method. ${ }^{63}$ The low fluorescence quantum yield in water (even in the presence of pyridine or DMSO) precluded the determination of TPA properties in water by the fluorescence method. Therefore the two-photon excitation spectrum was obtained in DMSO at a concentration of $10^{5} \mathrm{M}$ (Figure 4). The compound displays a large band in the 870-940 nm range with intense TPA cross-section above $7000 \mathrm{GM}$ and a maximum observed at $920 \mathrm{~nm}$ with a $\sigma_{2}$ value of $9400 \mathrm{GM}$. The values of $\sigma_{2}$ below $860 \mathrm{~nm}$ were discarded due to the progressive loss of the quadratic dependency of the fluorescence intensity $v s$ the power of the laser excitation beam ascribed to the contribution of the one-photon lowest energy $\mathrm{Q}$ band absorption. 


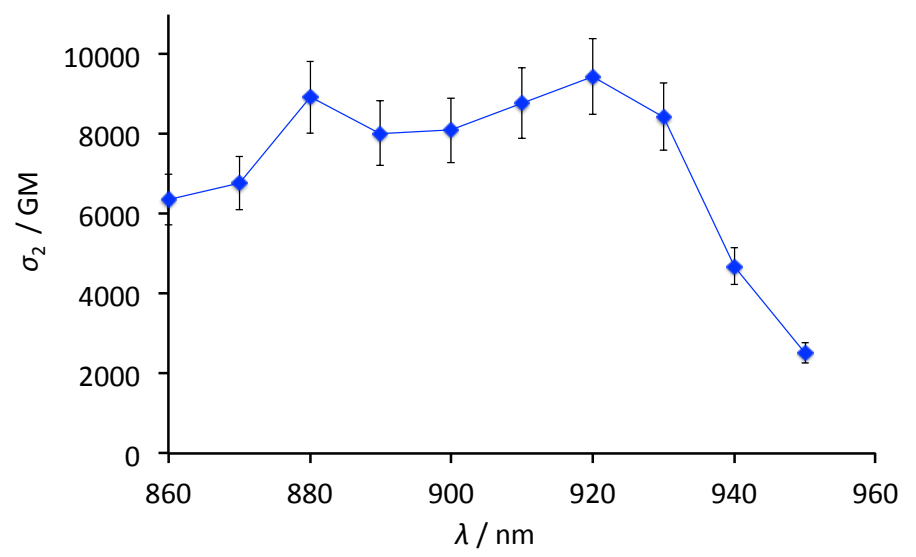

Figure 4. Two-photon excitation spectrum of 1 in DMSO.

Ethynylene-conjugated porphyrin dimers have indeed attracted attention since the highlight of their very efficient two-photon absorption properties. The electronic structure of $\mathbf{1}$ is similar to the one of butadiyne-bridged porphyrins described by Drobizhev et al. ${ }^{\circ}$ and Anderson et al. ${ }^{51}$ and the two-photon absorption cross-sections were found to be in the same range. For twophoton PDT applications, a relevant parameter for the PS is expressed by the two-photon singlet oxygen sensitization value $\left(\sigma_{2} \cdot \phi_{\Delta}\right)$, which is around $3400 \mathrm{GM}$ for 1 in DMSO at $930 \mathrm{~nm}$. This high value, obtained for an excitation within the optical therapeutic window, highlights the potential of this compound to behave as a promising photosensitizer for two-photon excited PDT.

\section{Cell penetration, subcellular localization and cytotoxicity}

Cell penetration capacity and subcellular localization of the PS influence strongly the efficiency of the PDT treatment. The cellular behavior of 1 was studied on HeLa cell cultures. As for the anionic Gd(III) containing sensitizer DPP-ZnP-GdDOTA, the cell penetration is rather slow at $1 \mu \mathrm{M}$ compared to the sensitizer without gadolinium complex..$^{49}$ After $24 \mathrm{~h}$, the fluorescent signal was found to be stable in cells and further studies were performed after $24 \mathrm{~h}$ incubation in the culture medium (DMEM) at $1 \mu \mathrm{M}$. The uptake of $\mathbf{1}$ in HeLa cells was quantitatively assessed by measuring the Gd content in cells by ICP-MS. This uptake was compared with the cellular uptake of a commercial contrast agent $[\mathrm{GdDTPA}]^{2}$ at an equivalent Gd incubation concentration $(2 \mu \mathrm{M}$ and $4 \mu \mathrm{M})$. As expected, the extracellular contrast agent [GdDTPA] ${ }^{2}$ hardly penetrates in the cells (Figure S14). By contrast, compound 1 was able to enter in the cells and the cellular uptake strongly increased with the incubation concentration. The cellular uptake was 26 times higher than the one obtained with [GdDTPA] at the Gd incubation concentration of $4 \mu \mathrm{M}$. This result shows the benefit of the design of an amphiphilic PS with a 
large lipophilic core and hydrophilic complexes on the periphery to increase the concentration of the contrast agents in tumor cells.

Subcellular localization was detected by colocalization studies using fluorescent dyes for nuclei (Hoechst 33258), mitochondria (Mitotracker green) and lysosomes (Lysotracker blue). None of these cell constituents were targeted by the theranostic agent as shown by the absence of a clear colocalization with these three reference probes (Figure 5). Compound 1 shows a diffuse localization in the cytoplasm with higher accumulation in bright spots, probably endosomes. ${ }^{4 s}$

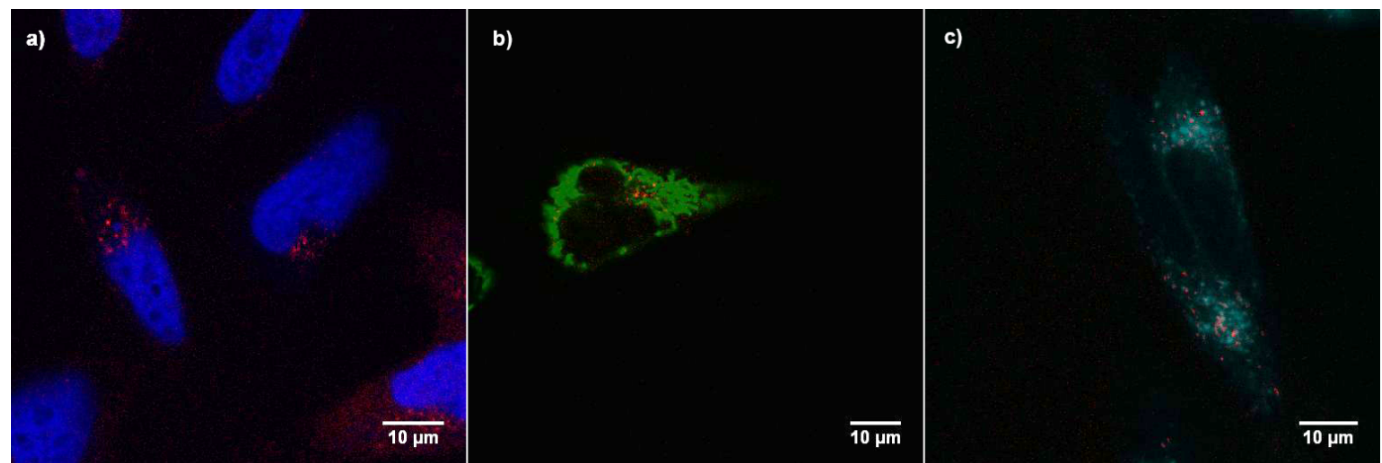

Figure 5. Confocal fluorescence images of HeLa cells incubated with $1(1 \mu \mathrm{M}, 24 \mathrm{~h})$ detected by its red fluorescence $\left(\lambda_{\mathrm{cx}}: 488 \mathrm{~nm}, \lambda_{\mathrm{cm}}: 700-800 \mathrm{~nm}\right)$; the cells are co-stained with a) Hoechst $33258\left(\lambda_{\mathrm{ex}}: 405 \mathrm{~nm}, \lambda_{\mathrm{em}}: 425-500 \mathrm{~nm}\right)$, b) Mitotracker green $\left(\lambda_{\mathrm{ex}}: 488 \mathrm{~nm}, \lambda_{\mathrm{cm}}: 500-600 \mathrm{~nm}\right)$ and c) Lysotracker blue $\left(\lambda_{\mathrm{ex}}: 405 \mathrm{~nm}, \lambda_{\mathrm{em}}: 425-500 \mathrm{~nm}\right)$. Scale bar: $10 \mu \mathrm{m}$

We then examined the toxicity of the compound in the absence of light. HeLa cells were incubated with compound 1 at concentrations ranging from 0.5 to $16 \mu \mathrm{M}$ during $24 \mathrm{~h}$. Compound 1 showed low cytotoxicity for concentrations lower than $2.5 \mu \mathrm{M}$, with an $\mathrm{IC}_{50}$ value of $10 \mu \mathrm{M}$ (Figure 6). This cytotoxicity is comparable to many other sensitizing agents containing porphyrins, being in the $1-30 \mu \mathrm{M}$ range..$^{65,66}$

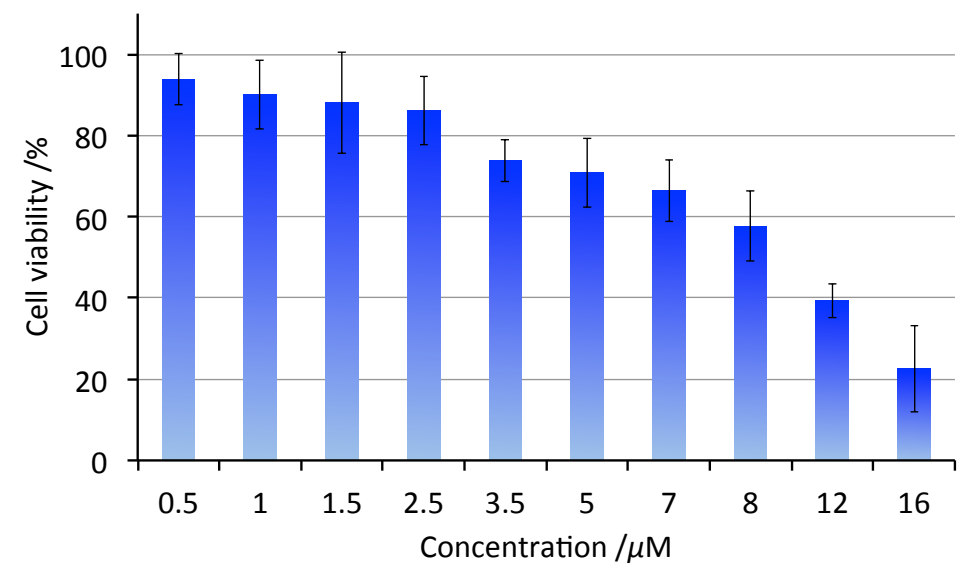

Figure 6. Cytotoxicity evaluation of $\mathbf{1}$ on HeLa cell culture after $24 \mathrm{~h}$ incubation 


\section{Phototoxicity evaluation following one-photon excitation.}

The red-extended intense absorption of this new molecule $\left(\varepsilon=1.17 \times 10^{5} \mathrm{M}^{-1} \mathrm{~cm}^{-1}\right.$ at $746 \mathrm{~nm}$ in DMSO, Table 2) makes it appealing as one-photon PS for PDT with irradiation in the nearinfrared (Figure 7). One-photon phototoxicity was evaluated as previously reported ${ }_{48,49}$ by irradiation of HeLa cells incubated for $24 \mathrm{~h}$ with $1(1 \mu \mathrm{M})$ at $740 \mathrm{~nm}$, with a fluence of 23 $\mathrm{mW} / \mathrm{cm}^{2}$, followed by an MTT cell toxicity test.

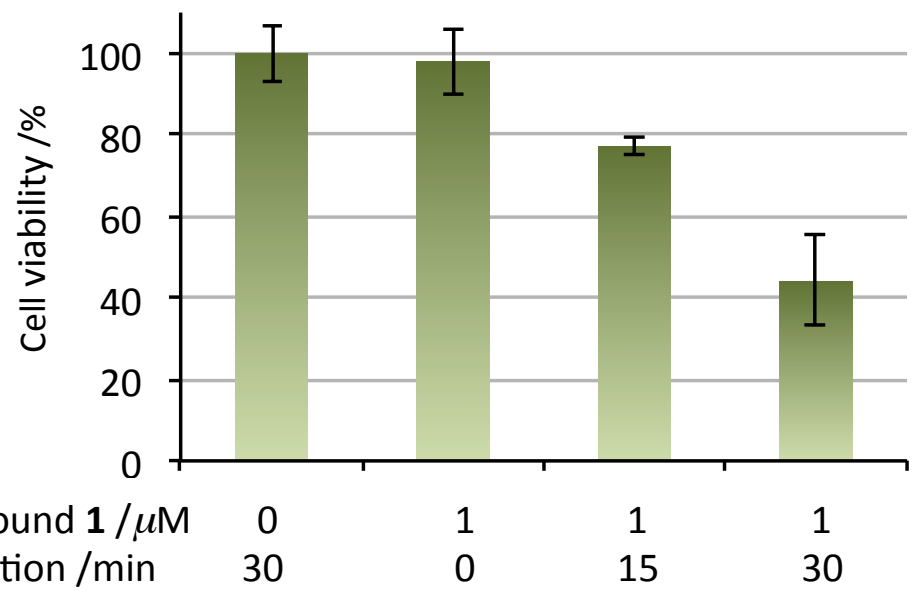

Figure 7. Viability of HeLa cells upon incubation of $1(1 \mu \mathrm{M})$ for $24 \mathrm{~h}$ followed by 0,15 or 30 min of one-photon irradiation at $740 \mathrm{~nm}$. Two control experiments corresponding to irradiated/non-irradiated cells in absence/presence of compound $\mathbf{1}$ are also shown.

Neither irradiation alone at $740 \mathrm{~nm}$ for 30 min nor incubation of the photosensitizer at $1 \mu \mathrm{M}$ without irradiation induced significant cell death (Figure 7), as expected by the use of near IR light and by the low dark toxicity of $\mathbf{1}$ at $1 \mu \mathrm{M}$. Conversely, a significant phototoxicity was already observed after 15 min irradiation, whereas $50 \%$ of cell death was obtained after 30 min of irradiation. In these conditions, the light dose to induce $50 \%$ cell death $\mathrm{LD}_{50}$ was $40 \mathrm{~J} / \mathrm{cm}^{2}$.

Phototoxicity evaluation following two-photon excitation. Two-photon phototoxicity of 1 on HeLa cell cultures was performed using a femtosecond laser and evaluated in two ways, by following the cell morphology modifications just after two-photon irradiation and by evaluating the cell viability, 4 hours after two-photon irradiation. Directly after the excitation with an average power of $77 \mathrm{~mW}$ at the pupil of the objective, HeLa cells showed only small cell shrinkage but did not evidence any sign of cell death. After $10 \mathrm{~min}$, formation of bubbles was detected on all cells, indicating an efficient TP induced phototoxicity (Figure 8). Control 
experiments performed at the same excitation power without the PS did not exhibit any variation in the cell morphology (Figure S15).

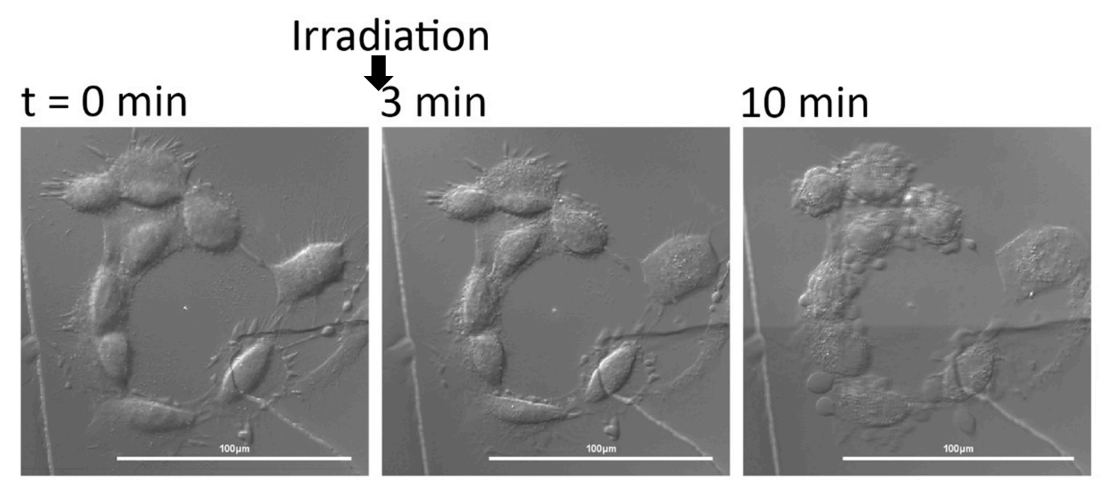

Figure 8. DIC images of HeLa cells incubated with $1(2 \mu \mathrm{M}, 24 \mathrm{~h})$ before $(\mathrm{t}=0 \mathrm{~min})$ and after TP irradiation ( $\mathrm{t}=3$ and $10 \mathrm{~min}$ ) performed at $910 \mathrm{~nm}$ with 300 scans ( $77 \mathrm{~mW}$ at the back pupil of the objective). Scale bar: $100 \mu \mathrm{m}$

For a quantitative assessment of this phototoxicity, cells were irradiated in the same way as before and then incubated for 4 hours before performing a cell viability test using Hoechst and Sytox orange dyes as described previously ${ }^{48,49}$ Figure 9 shows the images of the cell viability tests using excitation powers up to about $200 \mathrm{~mW}$. Control experiments with irradiation but without the PS were performed and no phototoxicity was detected below an average power of $200 \mathrm{~mW}$ measured at the back pupil of the objective. Cell death after incubation with $\mathbf{1}(2 \mu \mathrm{m}$, 24 hours) and two-photon irradiation was not significant below $30 \mathrm{~mW}$. Phototoxicity started to be more important after $77 \mathrm{~mW}$. Remarkably, with a light power of $108 \mathrm{~mW}, 100 \%$ of cell death was observed. (Figure 9 and Table S3). 


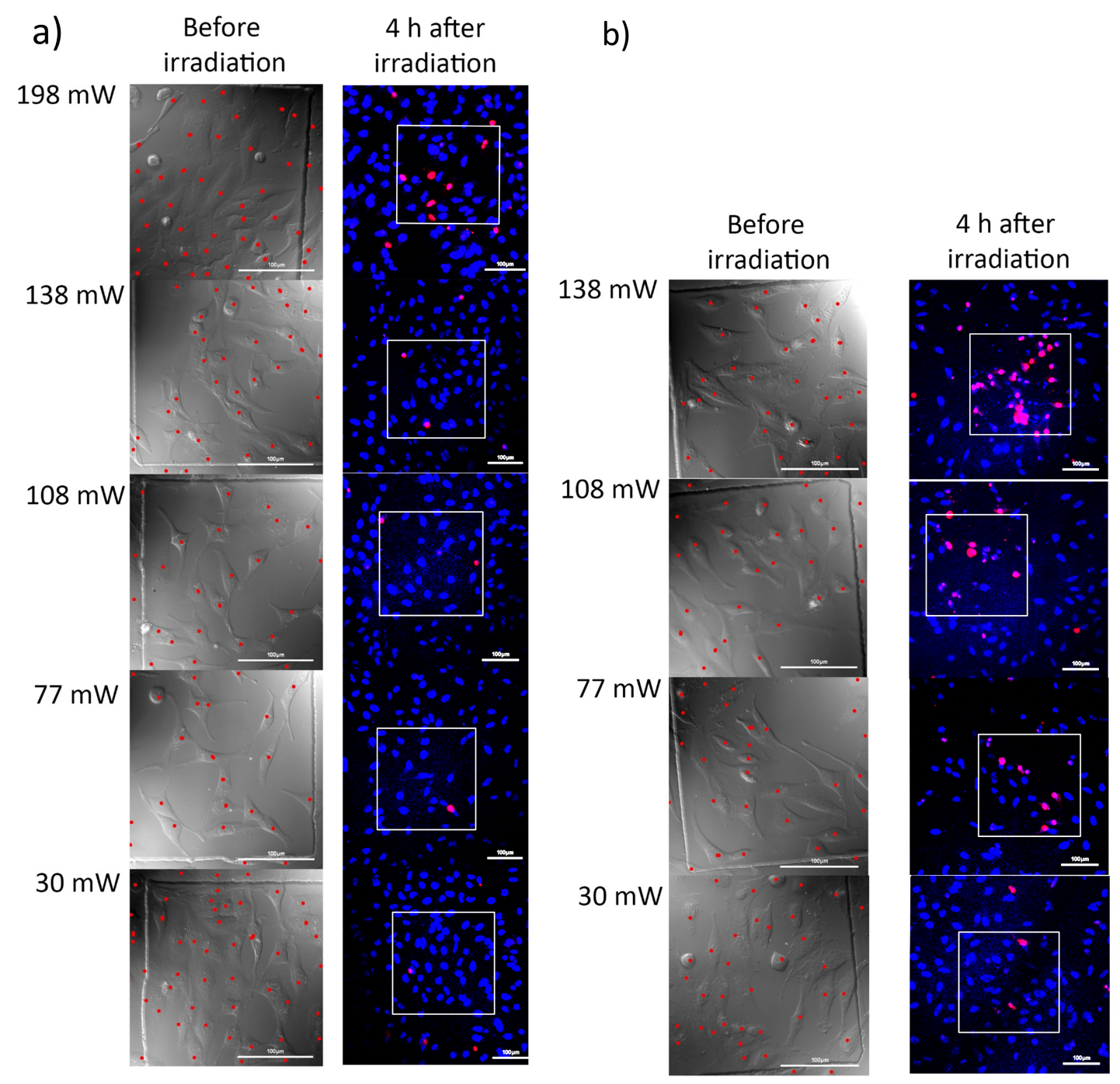

Figure 9. Images of HeLa cells obtained before irradiation (DIC images) and $4 \mathrm{~h}$ after twophoton irradiation at $910 \mathrm{~nm}$ (confocal images); a) Control experiments in the absence of PS; b) experiments in the presence of the PS $1(2 \mu \mathrm{M}$, incubation $24 \mathrm{~h})$. Cells counted before TP irradiation in the white square are highlighted with a red dot. All nuclei are stained with Hoescht (blue) and damaged cells are co-stained with Sytox orange (red). TP irradiation has been performed at different laser powers going from 30 to $198 \mathrm{~mW}$. Scale bar: $100 \mu \mathrm{m}$.

\section{- Conclusion}

A new theranostic agent designed to perform two functions, PDT in the optical therapeutic window and MRI detection was synthesized and characterized. This new molecule, consisting of a $\mathrm{Zn}(\mathrm{II})$ porphyrin dimer endowed with two GdDOTA-type complexes, behaves as a promising medium-size contrast agent, with a four time higher relaxivity $\left(14.4 \mathrm{mM}{ }^{-1} \cdot \mathrm{s}^{-1}\right.$ at 40 $\mathrm{MHz}$ per gadolinium at $25^{\circ} \mathrm{C}$ ) than the commercial contrast agents and thanks to its 
amphiphilicity, it is internalized in cancer cells. Moreover, with two gadolinium complexes, the value of relaxivity per molecule is twice as high, which is in favor of imaging at lower concentration. This agent has also shown appealing properties in solution as PDT photosensitizer regarding its solubility, its good ability to generate singlet oxygen and its high absorption in the near-infrared, above $700 \mathrm{~nm}$. It also offers another spectral window between $870-930 \mathrm{~nm}$, for deeper and highly selective treatment based on two-photon PDT, since it displays high two-photon cross sections above $7000 \mathrm{GM}$ in this spectral range. These features were confirmed with PDT experiments performed on cancer cells incubated at low concentration with the theranostic agent. Both one-photon light irradiation at $740 \mathrm{~nm}$ and twophoton light irradiation at $910 \mathrm{~nm}$ applied to the cell cultures led to important cell death in conditions where both the theranostic agent or the light excitation alone were non-toxic. Such behavior opens new perspectives for PDT with a PS than can be activated at different tissue depths with a classical protocol or a more selective one, depending on the size and localization of the tumor. With the association of a new kind of PDT drug and Gd(III) complexes for MRI, this theranostic agent offers new features regarding both its imaging capacity and its applications in fine-tuned therapy, in line with the current research of non-invasive and personalized treatments.

\section{- Experimental procedures}

All chemicals were of the best commercially available grade and used without further purification. Tetrahydrofuran was dried using a dry solvent station GT S100. Dry chloroform was obtained by distillation over $\mathrm{CaH}_{2}$ under nitrogen. Triethylamine $\left(\mathrm{Et}_{3} \mathrm{~N}, 99 \%\right)$, and anhydrous dimethyl sulfoxide (DMSO, 99.7\%) were purchased from Aldrich Chemicals (France). Analytical thin layer chromatography (TLC) was carried out on Merck aluminium backed silica gel 60 F254 plates and visualization when required was achieved using UV light. Precoated plates (PLC Silica gel $60 \mathrm{~F}_{254}, 2 \mathrm{~mm}$ ) were used for preparative thin-layer chromatography. Column chromatographies were carried out on silica (Fluka 60, 70-230 mesh). Size-exclusion chromatography was carried out using Bio-Beads S-X1, 200-400 mesh (BioRad). NMR spectra were recorded at $298 \mathrm{~K}$ using Bruker AVANCE 300, 400 or 500 spectrometers. Chemical shifts are quoted as parts per million ( $\mathrm{ppm}$ ) relative to the residual peak of solvent and coupling constants $(J)$ are quoted in Hertz $(\mathrm{Hz})$. The 2D-NMR techniques COSY and ROESY have been used to achieve full assignment of the signals. In the assignments, the chemical shift (in ppm) is given first, followed, in brackets, by the multiplicity 
of the signal ( $\mathrm{s}:$ singlet, $\mathrm{d}:$ doublet, $\mathrm{t}$ : triplet, $\mathrm{m}:$ multiplet, br $\mathrm{s}:$ broad signal), the value of the coupling constants in hertz if applicable, the number of protons implied, and finally the assignment. UV-vis spectra were recorded on a UVIKON XL spectrophotometer. Mass spectra were obtained by using a Bruker MicroTOF spectrometer (ES-MS). ICP-MS was performed with an Agilent 7500ce spectrometer. ICP-AES was performed by emission spectrometry with a Varian 720-ES spectrophotometer. The compounds TIPS-ZnP ${ }^{s}$, TIPS-ZnP-ZnP-TIPS ${ }^{52}$ tert-butoxycarbonyl (Boc)-protected 3-iodobenzylamine (I-Bn-NHBoc) $)^{54}, \mathrm{Na}_{2}[\mathrm{GdDOTAGA}]^{5 s}$ and $\mathrm{Na}_{2}$ [YDOTAGA] $]^{\text {s5 }}$ were prepared according to the literature.

Synthesis of BocHN-ZnP-ZnP-NHBoc. To a degassed solution of TIPS-ZnP-ZnPTIPS $(113 \mathrm{mg}, 41 \mu \mathrm{mol})$ in dry THF $(10 \mathrm{~mL})$ was added, under argon, a solution of tetrabutylammonium fluoride $(26 \mathrm{mg}, 82 \mu \mathrm{mol})$ in dry THF $(1 \mathrm{~mL})$. The reaction mixture was stirred at room temperature for 20 minutes and then, anhydrous calcium chloride (93 mg, 0.82 mmol) was added. The solvent was evaporated and the crude was submitted to a silica gel column chromatography (DCM/MeOH 96:4). Due to its instability, the deprotected compound H-ZnP-ZnP-H obtained as a brown-green solid was rapidly used for the next reaction. H-ZnPZnP-H, $\mathrm{Pd}_{2}(\mathrm{dba})_{3}(3.8 \mathrm{mg}, 4 \mu \mathrm{mol})$, CuI (2 mg, $\left.11 \mu \mathrm{mol}\right), \mathrm{PPh}_{3}(5.4 \mathrm{mg}, 20 \mu \mathrm{mol})$ and Bocprotected 3-iodobenzylamine (36 mg, $107 \mu \mathrm{mol}$ ) were dried under vacuum for 1 hour at $45^{\circ} \mathrm{C}$. A solution of dry THF $(10 \mathrm{~mL})$ and $\mathrm{Et}_{3} \mathrm{~N}(5 \mathrm{~mL})$ degassed by four freeze-thaw cycles was transferred via cannula to the solids placed under argon. The resulting mixture was stirred at $50^{\circ} \mathrm{C}$ for 2 hours. The solvents were evaporated and the product was purified by silica gel column chromatography (DCM / pyridine 1\%/ MeOH 1.5 to 2.5\%). BocHN-ZnP-ZnP-NHBoc was obtained as a brown-green solid in $68 \%$ yield $(80 \mathrm{mg}) . \mathbf{H} \mathbf{~ N M R}\left(500 \mathrm{MHz}, \mathrm{CDCl}_{3}+1 \%\right.$ pyridine $): \delta=1.50\left(\mathrm{~s}, 18 \mathrm{H}, \mathrm{H}_{10}\right), 3.29\left(\mathrm{~s}, 24 \mathrm{H}, \mathrm{H}_{1}\right), 3.47-3.49\left(\mathrm{~m}, 16 \mathrm{H}, \mathrm{H}_{2}\right), 3.60-3.62(\mathrm{~m}, 16 \mathrm{H}$, $\left.\mathrm{H}_{3}\right), 3.67-3.69\left(\mathrm{~m}, 16 \mathrm{H}, \mathrm{H}_{4}\right), 3.76-3.78\left(\mathrm{~m}, 16 \mathrm{H}, \mathrm{H}_{5}\right), 3.93-3.94\left(\mathrm{~m}, 16 \mathrm{H}, \mathrm{H}_{6}\right), 4.31-4.33(\mathrm{~m}, 16 \mathrm{H}$, $\left.\mathrm{H}_{7}\right), 4.43\left(\mathrm{~d}, J=5.2 \mathrm{~Hz}, 4 \mathrm{H}, \mathrm{H}_{8}\right), 5.30$ (br s, 2H, $\left.\mathrm{H}_{9}\right), 6.94(\mathrm{t}, J=2.0 \mathrm{~Hz}, 4 \mathrm{H}, \mathrm{p}), 7.38$ (d, $J=2.3$ $\mathrm{Hz}, 8 \mathrm{H}, \mathrm{o}), 7.56$ (d, J=7.9 Hz, 4H, m'), 7.97 (d, $J=7.9 \mathrm{~Hz}, 4 \mathrm{H}, \mathrm{o}$ '), 8.91 (d, $J=4.6 \mathrm{~Hz}, 4 \mathrm{H}$, $\left.\mathrm{py}_{3}\right), 9.00\left(\mathrm{~d}, J=4.6 \mathrm{~Hz}, 4 \mathrm{H}, \mathrm{py}_{2}\right), 9.67\left(\mathrm{~d}, J=4.6 \mathrm{~Hz}, 4 \mathrm{H}, \mathrm{py}_{4}\right), 9.84 \mathrm{ppm}(\mathrm{d}, J=4.6 \mathrm{~Hz}, 4 \mathrm{H}$, py). ${ }^{13}$ C NMR (125 MHz, $\mathrm{CDCl}_{3}+1 \%$ pyridine) $: \delta=28.59,44.73,59.11,67.80,70.68,70.78$, $71.00,72.01,82.35,88.45,93.42,96.42,99.38,101.07,101.91,114.86,122.71,127.91,130.85$, $130.89,131.92,132.61,133.09,139.59,144.55,149.74,150.10,152.02,153.35,156.20$, 157.98 ppm. ES-MS : $m / z \quad(\%) \quad 1449.53 \quad(100) \quad[\mathrm{M}+2 \mathrm{Na}]^{2+} / 2 \quad($ calcd 1449.55 for $\left.\left[\mathrm{C}_{152} \mathrm{H}_{180} \mathrm{~N}_{10} \mathrm{O}_{33} \mathrm{Zn}_{2} \mathrm{Na}_{2}\right]^{2+} / 2\right)$. 
Synthesis of $\mathbf{H}_{2} \mathbf{N}-Z n P-Z n P-N_{2}$. Compound BocHN-ZnP-ZnP-NHBoc (80 mg, 28 $\mu \mathrm{mol})$ was dissolved in dry DCM $(20 \mathrm{~mL})$ and the solution was cooled to $0^{\circ} \mathrm{C}$. Trifluoroacetic acid $(0.5 \mathrm{~mL})$ was added dropwise and the solution was stirred overnight at room temperature. The organic phase was washed with water $(10 \mathrm{~mL})$ and aqueous saturated $\mathrm{NaHCO}_{3}(10 \mathrm{~mL})$. The organic layer was dried over $\mathrm{Na}_{2} \mathrm{SO}_{4}$, filtered and evaporated. The crude product was dissolved in dry $\mathrm{CHCl}_{3}(20 \mathrm{~mL})$ and a solution of $\mathrm{Zn}(\mathrm{OAc})_{2} .2 \mathrm{H}_{2} \mathrm{O}(62 \mathrm{mg}, 0.28 \mathrm{mmol})$ in $\mathrm{MeOH}$ $(2 \mathrm{~mL})$ was added dropwise. The resulting mixture was stirred at $50^{\circ} \mathrm{C}$ for 5 hours. After evaporation of the solvents, DCM $(10 \mathrm{~mL})$ was added and the solution was washed twice with brine $(2 \times 10 \mathrm{~mL})$ then with water $(10 \mathrm{~mL})$. The organic layer was dried over $\mathrm{Na}_{2} \mathrm{SO}_{4}$, filtered

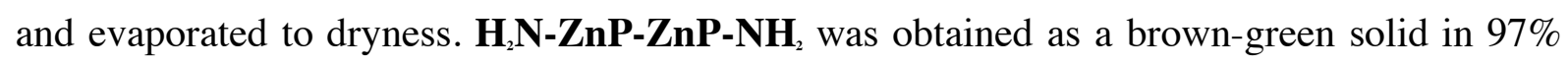
yield (72 mg). ${ }^{\mathbf{H}}$ NMR (500 MHz, $\mathrm{CDCl}_{3}+1 \%$ pyridine) $: \delta=3.30\left(\mathrm{~s}, 24 \mathrm{H}, \mathrm{H}_{1}\right), 3.48-3.50(\mathrm{~m}$, $\left.16 \mathrm{H}, \mathrm{H}_{2}\right), 3.61-3.63\left(\mathrm{~m}, 16 \mathrm{H}, \mathrm{H}_{3}\right), 3.67$ (br s, 4H, $\left.\mathrm{H}_{8}\right), 3.68-3.70\left(\mathrm{~m}, 16 \mathrm{H}, \mathrm{H}_{4}\right), 3.77-3.79(\mathrm{~m}, 16 \mathrm{H}$, $\left.\mathrm{H}_{5}\right), 3.94-3.96\left(\mathrm{~m}, 16 \mathrm{H}, \mathrm{H}_{6}\right), 4.32-4.34\left(\mathrm{~m}, 16 \mathrm{H}, \mathrm{H}_{7}\right), 6.95(\mathrm{t}, J=2.1 \mathrm{~Hz}, 4 \mathrm{H}, \mathrm{p}), 7.31(\mathrm{~d}, J=7.8$ Hz, 4H, m'), 7.40 (d, $J=2.1 \mathrm{~Hz}, 8 \mathrm{H}, \mathrm{o}), 7.95$ (d, $\left.J=7.9 \mathrm{~Hz}, 4 \mathrm{H}, \mathrm{o}^{\prime}\right), 8.92$ (d, $J=4.6 \mathrm{~Hz}, 4 \mathrm{H}$, $\left.\mathrm{py}_{3}\right), 9.01\left(\mathrm{~d}, J=4.6 \mathrm{~Hz}, 4 \mathrm{H}, \mathrm{py}_{2}\right), 9.68\left(\mathrm{~d}, J=4.6 \mathrm{~Hz}, 4 \mathrm{H}, \mathrm{py}_{4}\right), 9.85 \mathrm{ppm}(\mathrm{d}, J=4.6 \mathrm{~Hz}, 4 \mathrm{H}$, py $\left._{1}\right) .{ }^{3} \mathbf{C ~ N M R}\left(125 \mathrm{MHz}, \mathrm{CDCl}_{3}+1 \%\right.$ pyridine) $: \delta=29.85,46.17,59.15,70.01,70.71,70.81$, 71.03, 72.04, 82.37, 88.47, 93.21,96.63, 99.36, 101.11, 102.13, 114.89, 122.71, 122.82, 127.38, $130.86,130.96,131.88,133.11,143.19,144.60,149.75,150.11,152.06,158.01$ ppm. HR ESMS : $m / z(\%) 1338.9996(100)[\mathrm{M}+2 \mathrm{Na}]^{2+} / 2\left(\right.$ calcd 1338.9986 for $\left.\left[\mathrm{C}_{140} \mathrm{H}_{165} \mathrm{~N}_{10} \mathrm{O}_{36} \mathrm{Zn}_{2} \mathrm{Na}_{2}\right]^{2+} / 2\right)$.

Synthesis of compounds 1 and 2. A solution of the complex $\mathbf{N a}_{2}$ [MDOTAGA](19.7 mmol. $\left.\mathrm{L}^{-1}, 89 \mu \mathrm{mol}\right)$ in dry DMSO under argon was obtained after 5 hours stirring at $60^{\circ} \mathrm{C}$. TBTU (31 mg, $98 \mu \mathrm{mol})$ and DIPEA (30 $\mu \mathrm{L}, 178 \mu \mathrm{mol})$ were added to the resulting solution. A solution of $\mathbf{H}_{2} \mathbf{N}-\mathbf{Z n P}-\mathbf{Z n P}-\mathbf{N H}_{2}(72 \mathrm{mg}, 28 \mu \mathrm{mol})$ in dry DMSO (4 mL) was then added dropwise. The reaction mixture was stirred at room temperature overnight. The compound was isolated by precipitation with addition of DCM $(4 \mathrm{~mL})$. After filtration, the solid was washed with DCM, acetone and water and dried under vacuum.

Characterization data of the gadolinium(III) complex 1: dark-green solid (58 mg, 52\%) UVvis. (DCM): $\lambda_{\max }(\log \varepsilon)=464$ (5.64), 498 (5.21) 587 (4.31), 680 (4.94), 745 nm (5.04). HR ESMS : $m / z(\%) 1938.5846(100) \quad\left[\mathrm{M}-2 \mathrm{H}_{2} \mathrm{O}\right]^{2 / 2}$ (calcd 1938.5999 for $\left[\mathrm{C}_{180} \mathrm{H}_{216} \mathrm{Gd}_{2} \mathrm{~N}_{18} \mathrm{O}_{50} \mathrm{Zn}_{2}\right]^{2} / 2$, 100\%). ICP-AES : [Gd] = $13.1 \pm 0 .<1 \mathrm{mg} / \mathrm{kg}=83.3 \pm 0.6 \mathrm{mmol} / \mathrm{kg},[\mathrm{Zn}]=5.64 \pm 0.04 \mathrm{mg} / \mathrm{kg}$ $=86.2 \pm 0.6 \mathrm{mmol} / \mathrm{kg}$.

Characterization data of the yttrium(III) complex 2: dark-green solid (40 mg, 55\%). $\mathbf{H}$ NMR (500 MHz, DMSO) : $\delta=1.70-1.88\left(\mathrm{~m}, 4 \mathrm{H}, \mathrm{H}_{10}\right), 2.21-2.84(\mathrm{~m}, 50 \mathrm{H}$, DOTA $), 3.19\left(\mathrm{~s}, 24 \mathrm{H}, \mathrm{H}_{1}\right)$, 
3.39-3.41 (m, 16H, $\left.\mathrm{H}_{2}\right), 3.51-3.53\left(\mathrm{~m}, 16 \mathrm{H}, \mathrm{H}_{3}\right), 3.57-3.58\left(\mathrm{~m}, 16 \mathrm{H}, \mathrm{H}_{4}\right), 3.64-3.65\left(\mathrm{~m}, 16 \mathrm{H}, \mathrm{H}_{5}\right)$, $3.86\left(\mathrm{~m}, 16 \mathrm{H}, \mathrm{H}_{6}\right), 4.35\left(\mathrm{~m}, 16 \mathrm{H}, \mathrm{H}_{7}\right), 4.42-4.49\left(\mathrm{~m}, 4 \mathrm{H}, \mathrm{H}_{8}\right), 7.05(\mathrm{~m}, 4 \mathrm{H}, \mathrm{p}), 7.37(\mathrm{~m}, 8 \mathrm{H}, \mathrm{o})$, 7.52 (d, 4H, $\left.J=7.3 \mathrm{~Hz}, \mathrm{~m}^{\prime}\right), 8.10$ (d, $J=7.5 \mathrm{~Hz}, 4 \mathrm{H}, \mathrm{o}$ '), 8.55 (br s, 2H, H, $), 8.91$ (d, $J=4.1$ $\left.\mathrm{Hz}, 4 \mathrm{H}, \mathrm{py}_{3}\right), 9.00\left(\mathrm{~d}, J=4.0 \mathrm{~Hz}, 4 \mathrm{H}, \mathrm{py}_{2}\right), 9.71\left(\mathrm{~d}, J=4.3 \mathrm{~Hz}, 4 \mathrm{H}, \mathrm{py}_{4}\right), 9.83 \mathrm{ppm}(\mathrm{d}, J=4.3$ $\mathrm{Hz}, 4 \mathrm{H}, \mathrm{py}_{1}$ ). HR ES-MS : m/z 1870.0761 (100) $\left[\mathrm{M}-2 \mathrm{H}_{2} \mathrm{O}\right]^{2 / 2}$ (calcd 1870.0816 for $\left.\left[\mathrm{C}_{180} \mathrm{H}_{216} \mathrm{Y}_{2} \mathrm{~N}_{18} \mathrm{O}_{s \mathrm{i}} \mathrm{Zn}_{2}\right]^{2} / 2,100 \%\right)$.

Relaxometric measurements. ${ }^{H} \mathrm{H}$ NMR profiles $([1]=0.81 \mathrm{mM}, \mathrm{pH}=6.6$ in $2 \%$ pyridine $/ \mathrm{H}_{2} \mathrm{O}$ ) were recorded on a Stelar SMARTracer Fast Field Cycling relaxometer (0.01-10 MHz) and a Bruker WP80 NMR electromagnet adapted to variable field measurements (20-80 $\mathrm{MHz}$ ) and controlled by a SMARTracer PC-NMR console. Higher field relaxivities were measured on Bruker AVANCE NMR spectrometers at $300 \mathrm{MHz}, 400 \mathrm{MHz}$, and $600 \mathrm{MHz}$. The temperature was monitored by a VTC91 temperature control unit and maintained by a gas flow and was determined by previous calibration with a Pt resistance temperature probe. The leastsquare fit of the 'H NMRD data was performed using Visualiseur/Optimiseur ${ }^{\circ / 7}$ running on a MATLAB 8.3.0 (R2014a) platform. The relaxivity was also measured in the presence of BSA (42.7 g.L $\mathrm{L}^{-1}$ ) for [1] $=0.60 \mathrm{mM}$ at 298 and $310 \mathrm{~K}$ and $40 \mathrm{MHz}$. The exact Gd(III) ion concentration was determined by ICP-MS analysis after microwave-assisted mineralization.

One-photon spectroscopy and photophysics. Spectroscopic grade DMSO was purchased from Carlo Erba. Pyridine, 1,3-diphenylisobenzofuran (DPBF), Zn-phthalocyanine $(\mathrm{ZnPc})$ and 5,10,15,20-tetrakis(4-sulfonatophenyl)porphyrin (TPPS ${ }_{4}$ ) were from Aldrich. Tridistilled (Millipore Milli-Q) $\mathrm{H}_{2} \mathrm{O}$ was used and the solutions prepared with $1 \%$ of pyridine were adjusted to $\mathrm{pH}=7$ with microadditions of diluted $\mathrm{HCl}$ aqueous solutions. Absorption spectra were recorded with a Perkin-Elmer Lambda 650 UV-Vis spectrophotometer. Molar absorption coefficients in $\mathrm{H}_{2} \mathrm{O}$ added with $1 \%$ pyridine and $1 \%$ DMSO were derived from that in DMSO by vacuum drying a DMSO solution of known concentration and adding the aqueous solvent. Emission spectra were collected with an FLS920 fluorimeter (Edinburgh) equipped with an Hamamatsu R5509-72 InP/InGaAs photomultiplier tube supercooled at $193 \mathrm{~K}$ in a liquid nitrogen cooled housing and a TM300 emission monochromator with a NIR grating blazed at $1000 \mathrm{~nm}$ (sensitivity range: 300-1700 nm). The spectra have been corrected for the wavelength dependent phototube response. The fluorescence quantum yields have been determined with reference to TPP (tetra-phenyl-porphyrin) in aerated toluene $\left(\phi_{n}=0.11\right)^{\text {ss. }}$. Fluorescence lifetimes have been measured with an IBH Time Correlated Single Photon Counting apparatus with nanoLED excitation at $465 \mathrm{~nm}$. The analysis of the luminescence decay profiles against time 
was accomplished with the DAS6 Decay Analysis Software provided by the manufacturer. Estimated errors are $10 \%$ on exponential lifetimes, $20 \%$ on quantum yields, $20 \%$ on molar absorption coefficients and $3 \mathrm{~nm}$ on emission and absorption peaks. Singlet oxygen production quantum yields in DMSO have been measured with a comparative method using DPBF as a singlet oxygen trap..$^{60} \mathrm{ZnPc}$ has been used as a standard $\left(\phi_{\Delta}=0.67\right) .{ }^{70}$ Solutions of the standard or of compound 1 containing DPBF $2.2 \times 10^{s} \mathrm{M}$, prepared in the dark, have been irradiated at $680 \mathrm{~nm}$ by using an irradiation set-up composed by a $150 \mathrm{~W}$ Xenon lamp (LOT) and a Omni$\lambda 150$ monochromator (Zolix) with a $16 \mathrm{~nm}$ slit and completed by a $635 \mathrm{~nm}$ cutoff filter, under continuous stirring. The light intensity was $3.5 \mathrm{~mW} / \mathrm{cm}^{2}$. The decrease of DPBF absorption, derived by subtracting the constant absorption contribution of $\mathbf{1}$ or the standard from the spectrum of the mixture, has been followed at $418 \mathrm{~nm}$ (see Figures 3 and S12). Singlet oxygen quantum yields in $\mathrm{H}_{2} \mathrm{O}$ added with $1 \%$ pyridine and $1 \%$ DMSO have been derived with the same indirect method by using anthracene-9,10-dipropionic acid (ADPA) disodium salt as a singlet oxygen trap." ${ }^{7 P P S} S_{4}$ has been used as a standard $\left(\phi_{\Delta}=0.51\right) .^{2}$ Solutions of the standard or 1 containing $3.2 \times 10^{-5} \mathrm{M}$ ADPA, prepared in the dark, have been irradiated at $516 \mathrm{~nm}$ by using the same irradiation setup with a $16 \mathrm{~nm}$ slit and completed by a $500 \mathrm{~nm}$ cutoff filter, under continuous stirring. The light intensity was $2 \mathrm{~mW} / \mathrm{cm}^{2}$. The decrease of ADPA absorption has been followed at $378 \mathrm{~nm}$ (see Figure S13). The singlet oxygen quantum yield of the sample $\left(\phi_{\Delta}\right)$ has been determined by using equation (1):

(1) $\Phi_{\Delta}=\Phi_{\Delta}^{S t d} \frac{R . I_{a b s}^{S t d}}{R^{S t d} \cdot I_{a b s}}$ where $R$ and $R^{\text {su }}$ are the trap (DPBF or ADPA) degradation rates for the sample and the standard, respectively, and $I_{\text {abs }}$ is the absorption at the excitation wavelength calculated as described previously ${ }^{49}$

DLS measurements. The particle hydrodynamic diameter was measured using a NanoBrook Omni Analyzer from Brookhaven Instruments Corporation. Average particle size distributions were measured by means of dynamic light scattering at a fixed scattering angle of $90^{\circ}$ and at $25^{\circ} \mathrm{C}$. The hydrodynamic diameter was calculated applying an autocorrelation function to the scattered light intensity profile considering the particles as spheres. Red laser light $(640 \mathrm{~nm})$ was used in the scattering experiments. From four to five measurements were carried out for reproducibility in each solvent. Disposable polystyrene cuvettes were used. The concentration of $\mathbf{1}$ in both solvents was $2 \times 10^{-6} \mathrm{M}$. 
Two-photon spectroscopy. The two-photon excitation spectra was obtained by upconverted fluorescence measurements using a Ti:sapphire femtosecond laser Insight DS with pulse width $<120$ fs and a repetition rate of $80 \mathrm{MHz}$ (Spectra-Physics) as described previously. ${ }^{63}$ The excitation beam was collimated over the cell length $(10 \mathrm{~mm})$ and the fluorescence, collected at $90^{\circ}$ of the excitation beam, was focused into an optical fibber connected to a spectrometer. The incident beam intensity was adjusted to ensure an intensitysquared dependence of the fluorescence over the whole spectral range investigated. Calibration of the spectra was performed by comparison with the published rhodamine B TPA spectrum..$^{3}$

Cell culture and MTT cell viability test. HeLa cells were cultured in DMEM complete culture medium containing phenol red at $37^{\circ} \mathrm{C}$ with $5 \% \mathrm{CO}_{2}$. They were seeded and maintained in $25 \mathrm{~mL}$ Falcon culture flask or multi well LabTek (Lab-Tek ${ }^{\circledR}$ II) culture flasks. MTT toxicity tests were performed in pentaplicate with extemporaneous solutions of 3-(4,5-Dimethyl-2thiazolyl)-2,5-diphenyl-2H-tetrazolium bromide ( $50 \mu \mathrm{L}$ of a $5 \mathrm{mg} / \mathrm{mL}$ solution in DMEM by well). After an incubation period of 45 minutes, the media was removed and replaced by 150 $\mu \mathrm{L}$ of DMSO. The absorbance was measured in 96 well plates with a Safas Xenius spectrofluorimeter at $550 \mathrm{~nm}$.

HeLa cell preparation for Gd quantification by ICP-AES. HeLa cells were seeded in 6 wells LabTek culture plate in complete DMEM medium as described in the cell culture paragraph. The cultures were incubated with $1(1 \mu \mathrm{M})$ and [GdDTPA $]^{2}$ for 24 hours. They were then washed three times with PBS $(3 \times 2 \mathrm{~mL})$. Cells were suspended using trypsin $(0.5 \mathrm{~mL})$ and after 5 min DMEM $(9.5 \mathrm{~mL})$ was added and transferred in $10 \mathrm{~mL}$ Falcon tubes. The cells were counted using a Malassez cell. The culture medium was removed by gentle centrifugation at 60 $\times$ g. A $60 \%$ nitric acid solution was added to the centrifugation pellet and the cells were digested for 24 hours at room temperature. The Gd content in aqueous samples was determined by ICPAES after mineralization in an Anton Paar microwave oven (multiwave ECO 3000) with a nitric acid solution $\left(\mathrm{HNO}_{3} 20 \%\right.$ for trace analysis $\geq 69.0 \%$, TraceSELECT ${ }^{\circledR}$, from Fluka).

Dark cytotoxicity. HeLa cells were seeded in 96 wells culture plates and incubated with different concentrations of $\mathbf{1}$. After 24 hours the cell viability was estimated using previously described MTT test.

One-photon phototoxicity tests. One-photon phototoxicity tests were performed as described in the literature using a homemade apparatus ${ }^{4 s, 49}$ using $800 \mathrm{~mA}$ high power LED Far Red / Infra Red (740-745 nm) (FutureEden ${ }^{\mathrm{TM}}$ ) adapted for Corning ${ }^{\circledR} 96$ well special optic plates. Cells were cultured 1 day in these 96 well plates and incubated with $1 \mu \mathrm{M}$ solution of 
photosensitizer in complete DMEM medium for 24 hours. The medium was replaced by new DMEM free of sensitizer and the plates were irradiated for 15 or $30 \mathrm{~min}$. The LEDs power was measured with a Thorlabs PM100D power-meter. The cell viability was then estimated 24 hours after irradiation using previously described MTT test.

Two-photon phototoxicity tests. HeLa cells were plated at $25 \%$ confluence in IBIDI $\mu$-Dish $35 \mathrm{~mm}$, grid-500. After $24 \mathrm{~h}$ growth the culture medium was replaced by a fresh one containing $1(2 \mu \mathrm{M})$. Two-photon irradiation was performed after $24 \mathrm{~h}$ incubation, with a cell confluence of about $80 \%$ using a Leica SP5 inverted microscope with a HCX PL APO CS 40x oil Leica objective and a Coherent Chameleon Ultra 2 laser as fs laser source (150 fs pulses with a repetition rate of $80 \mathrm{MHz}$ set at $910 \mathrm{~nm}$ ). A region of $260 \times 260 \mu \mathrm{m}$ (zoom set to 1,5) was irradiated. The laser power was measured at the back pupil of the objective and set between 30 and $200 \mathrm{~mW}$. The focus plane was selected by DIC (differential interference contrast) microscopy $\left(\lambda_{\mathrm{ex}}=513 \mathrm{~nm}\right)$ to be at the bottom part of the cells. They were irradiated using a series of 10 slices (10 up the selected focal plane corresponding to the coverslip), with $1 \mu \mathrm{m} \mathrm{z}$ increments, with 30 scans per slice (300 scans in total). After irradiation the cells were imaged during $10 \mathrm{~min}$ in wild field DIC to detect morphological changes. For the cell viability tests, the irradiated cells were placed for $3 \mathrm{~h} 30$ in an incubator. Hoescht $33342(5 \mu \mathrm{g} / \mathrm{mL})$ and Sytox orange $(5 \mu \mathrm{M})$ were added and the cells placed in the incubator for another $30 \mathrm{~min}$ before imaging. Confocal images were obtained with a Leica TSP SPE microscope using two channels, one for Hoescht (ex. $405 \mathrm{~nm})$ and one for Sytox orange (ex. $561 \mathrm{~nm})$.

A control experiment was performed for each light power using the same conditions but without 1.

\section{- Associated content}

\section{Supporting information}

The Supporting Information is available free of charge on the ACS Publications website at DOI $\mathrm{XX}$

${ }^{1} \mathrm{H},{ }^{13} \mathrm{C}$ NMR and HR ES-MS of the synthetized compounds, excitation spectra of $\mathbf{1}$, quantum yield determination, Gd content per cell, cell DIC images after TP excitation, longitudinal relaxivity of $\mathbf{1}$ and estimation of cell viability after TP excitation.

\section{- Author information}




\section{Corresponding authors}

*E-mail:v.heitz@unistra.fr

*E-mail : frederic.bolze@unistra.fr

*E-mail : Eva.JAKABTOTH@cnrs.fr

*E-mail : barbara.ventura@isof.cnr.it

\section{Author contributions}

J.S and S.J. contributed equally.

\section{Notes}

The authors declare no competing financial interest

\section{- Acknowledgements}

The icFRC (http://www.icfrc.fr), LabEx CSC, and Region Alsace are gratefully acknowledged for a fellowship to J.S, and the Ministry of Education and Research is acknowledged for a Ph.D. fellowship to S.J. The Italian CNR (Project "PHEEL") and MIUR-CNR project Nanomax NCHEM are gratefully acknowledged. C.S.B. and E.T. thank the French Ligue contre le cancer for financial support. Dr. F. Manoli (ISOF-CNR) is acknowledged for a loan of ADPA and for support in DLS measurements. The authors are also grateful to Anne Boos and Pascale Ronot for ICP-AES measurements.

\section{- References}

NOTE 1 : Direct singlet oxygen phosphorescence analysis was precluded both in DMSO, due to the poor luminescence properties of singlet oxygen in this solvent, and in $\mathrm{H}_{2} \mathrm{O}$, due the required $\mathrm{pH}$ control which is less straightforward in $\mathrm{D}_{2} \mathrm{O}$, the solvent usually employed for direct phosphorescence measurement in aqueous environments because of the longer lifetime of ${ }^{\prime} \mathrm{O}_{2}$ in the deuterated solvent.

[1] Dougherty, T. J., Gomer, C. J., Henderson, B. W., Jori, G., Kessel, D., Korbelik, M., Moan, J., and Peng, Q. (1998) Photodynamic Therapy, J. Nat. Cancer Inst. 90, 889-905.

[2] Wilson, B. C., and Patterson, M. S. (2008) The physics, biophysics and technology of photodynamic therapy, Phys. Med. Biol. 53, R61-109.

[3] Ethirajan, M., Chen, Y., Joshi, P., and Pandey, R. K. (2011) The role of porphyrin chemistry in tumor imaging and photodynamic therapy, Chem. Soc. Rev. 40, 340-362.

[4] Ormond, A. B., and Freeman, H. S. (2013) Dye Sensitizers for Photodynamic Therapy, Materials 6, 817-840.

[5] Abrahamse, H., and Hamblin, M. R. (2016) New photosensitizers for photodynamic therapy, Biochem. J. 473, 347-364. 
[6] van Straten, D., Mashayekhi, V., de Bruijn, H. S., Oliveira, S., and Robinson, D., J. (2017) Oncologic Photodynamic Therapy: Basic Principles, Current Clinical Status and Future Directions, Cancers 9, 19.

[7] Azzouzi, A.-R., Vincendeau, S., Barret, E., Cicco, A., Kleinclauss, F., van der Poel, H. G., Stief, C. G., Rassweiler, J., Salomon, G., Solsona, E., Alcaraz, A., Tammela, T. T., Rosario, D. J., Gomez-Veiga, F., Ahlgren, G., Benzaghou, F., Gaillac, B., Amzal, B., Debruyne, F. M. J., Fromont, G., Gratzke, C., and Emberton, M. Padeliporfin vasculartargeted photodynamic therapy versus active surveillance in men with low-risk prostate cancer (CLIN1001 PCM301): an open-label, phase 3, randomised controlled trial, Lancet Oncol. 18, 181-191.

[8]http://www.ema.europa.eu/ema/index.jsp?curl=pages/medicines/human/medicines/004182/ human_med_002190.jsp\&mid=WC0b01ac058001d124.

[9] Pawlicki, M., Collins, H. A., Denning, R. G., and Anderson, H. L. (2009) Two-Photon Absorption and the Design of Two-Photon Dyes, Angew. Chem. Int. Ed. 48, 3244-3266.

[10] Bolze, F., Jenni, S., Sour, A., and Heitz, V. (2017) Molecular photosensitisers for twophoton photodynamic therapy, Chem. Commun. 53, 12857-12877.

[11] Gary-Bobo, M., Mir, Y., Rouxel, C., Brevet, D., Basile, I., Maynadier, M., Vaillant, O., Mongin, O., Blanchard-Desce, M., Morère, A., Garcia, M., Durand, J.-O., and Raehm, L. (2011) Mannose-Functionalized Mesoporous Silica Nanoparticles for Efficient TwoPhoton Photodynamic Therapy of Solid Tumors, Angew. Chem. Int. Ed. 50, 1142511429.

[12] Jia, J., Zhang, Y., Zheng, M., Shan, C., Yan, H., Wu, W., Gao, X., Cheng, B., Liu, W., and Tang, Y. (2018) Functionalized Eu(III)-Based Nanoscale Metal-Organic Framework To Achieve Near-IR-Triggered and -Targeted Two-Photon Absorption Photodynamic Therapy, Inorg. Chem. 57, 300-310.

[13] Hammerer, F., Poyer, F., Fourmois, L., Chen, S., Garcia, G., Teulade-Fichou, M.-P., Maillard, P., and Mahuteau-Betzer, F. (2018) Mitochondria-targeted cationic porphyrin-triphenylamine hybrids for enhanced two-photon photodynamic therapy, Bioorg. Med. Chem. 26, 107-118.

[14] Couleaud, P., Morosini, V., Frochot, C., Richeter, S., Raehm, L., and Durand, J.-O. (2010) Silica-based nanoparticles for photodynamic therapy applications, Nanoscale 2, 10831095.

[15] Kumar, R., Shin, W. S., Sunwoo, K., Kim, W. Y., Koo, S., Bhuniya, S., and Kim, J. S. (2015) Small conjugate-based theranostic agents: an encouraging approach for cancer therapy, Chem. Soc. Rev. 44, 6670-6683.

[16] Celli, J. P., Spring, B. Q., Rizvi, I., Evans, C. L., Samkoe, K. S., Verma, S., Pogue, B. W., and Hasan, T. (2010) Imaging and Photodynamic Therapy: Mechanisms, Monitoring, and Optimization, Chem. Rev. 110, 2795-2838.

[17] Terreno, E., Uggeri, F., and Aime, S. (2012) Image guided therapy: The advent of theranostic agents, J. Control. Release 161, 328-337.

[18] Eljamel, S. (2010) Photodynamic applications in brain tumors: A comprehensive review of the literature, Photodiagn. Photodyn. Ther. 7, 76-85.

[19] Eljamel, S., Petersen, M., Valentine, R., Buist, R., Goodman, C., Moseley, H., and Eljamel, S. (2013) Comparison of intraoperative fluorescence and MRI image guided neuronavigation in malignant brain tumours, a prospective controlled study, Photodiagn. Photodyn. Ther. 10, 356-361.

[20] Stummer, W., Pichlmeier, U., Meinel, T., Wiestler, O. D., Zanella, F., and Reulen, H.-J. r. (2006) Fluorescence-guided surgery with 5-aminolevulinic acid for resection of malignant glioma: a randomised controlled multicentre phase III trial, Lancet Oncol. 7, $392-401$. 
[21] Khurana, M., Ulrich, S., Kim, A., Moriyama, Y., Netchev, G., Akens, M. K., Anderson, H. L., and Wilson, B. C. (2012) Biodistribution and Pharmacokinetic Studies of a Porphyrin Dimer Photosensitizer (Oxdime) by Fluorescence Imaging and Spectroscopy in Mice Bearing Xenograft Tumors, Photochem. Photobiol. 88, 1531-1538.

[22] Patel, N. J., Chen, Y., Joshi, P., Pera, P., Baumann, H., Missert, J. R., Ohkubo, K., Fukuzumi, S., Nani, R. R., Schnermann, M. J., Chen, P., Zhu, J., Kadish, K. M., and Pandey, R. K. (2016) Effect of Metalation on Porphyrin-Based Bifunctional Agents in Tumor Imaging and Photodynamic Therapy, Bioconjugate Chem. 27, 667-680.

[23] Yuan, A., Wu, J., Tang, X., Zhao, L., Xu, F., and Hu, Y. (2013) Application of NearInfrared Dyes for Tumor Imaging, Photothermal, and Photodynamic Therapies, $J$. Pharm. Sci. 102, 6-28.

[24] Chitgupi, U., Qin, Y., and Lovell, J. F. (2017) Targeted Nanomaterials for Phototherapy, Nanotheranostics 1, 38-58.

[25] Kharroubi Lakouas, D., Huglo, D., Mordon, S., and Vermandel, M. (2017) Nuclear medicine for photodynamic therapy in cancer: Planning, monitoring and nuclear PDT, Photodiagn. Photodyn. Ther. 18, 236-243.

[26] Schreurs, T. J. L., Jacobs, I., Nicolay, K., Prompers, J. J., and Strijkers, G. J. (2017) Detection of Treatment Success after Photodynamic Therapy Using Dynamic ContrastEnhanced Magnetic Resonance Imaging, Theranostics 7, 4643-4657.

[27] Barrett, T., Davidson, S. R. H., Wilson, B. C., Weersink, R. A., Trachtenberg, J., and Haider, M. A. (2014) Dynamic contrast enhanced MRI as a predictor of vasculartargeted photodynamic focal ablation therapy outcome in prostate cancer post-failed external beam radiation therapy, Can. Urol. Assoc. J 8, E708-E714.

[28] Zilberstein, J., Schreiber, S., Bloemers, M. C. W. M., Bendel, P., Neeman, M., Schechtman, E., Kohen, F., Scherz, A., and Salomon, Y. (2001) Antivascular Treatment of Solid Melanoma Tumors with Bacteriochlorophyll-serine-based Photodynamic Therapy, Photochem. Photobiol. 73, 257-266.

[29] Schreurs, T. J. L., Hectors, S. J., Jacobs, I., Grüll, H., Nicolay, K., and Strijkers, G. J. (2016) Quantitative Multi-Parametric Magnetic Resonance Imaging of Tumor Response to Photodynamic Therapy, PLOS ONE 11, e0165759.

[30] Huang, Z., Haider, M. A., Kraft, S., Chen, Q., Blanc, D., Wilson, B. C., and Hetzel, F. W. (2006) Magnetic resonance imaging correlated with the histopathological effect of Pdbacteriopheophorbide (Tookad) photodynamic therapy on the normal canine prostate gland, Lasers Surg. Med. 38, 672-681.

[31] Kulik, M., Nedelcu, C., Martin, F., Lebdai, S., Rousselet, M. C., Azzouzi, A. R., and Aubé, C. (2014) Post-treatment MRI aspects of photodynamic therapy for prostate cancer, Insights Imaging 5, 697-713.

[32] Caravan, P., Ellison, J. J., McMurry, T. J., and Lauffer, R. B. (1999) Gadolinium(III) Chelates as MRI Contrast Agents: Structure, Dynamics, and Applications, Chem. Rev. 99, 2293-2352.

[33] Tóth, E., Helm, L., and Merbach, A. E. (2013) The Chemistry of Contrast Agents in Medical Magnetic Resonance Imaging, In The Chemistry of Contrast Agents in Medical Magnetic Resonance Imaging, pp 25 - 82, 2nd edn. Wiley and Sons, Relaxivity of Gadolinium(III) Complexes (Chapter 2)

[34] Werner, E. J., Datta, A., Jocher, C. J., and Raymond, K. N. (2008) High-Relaxivity MRI Contrast Agents: Where Coordination Chemistry Meets Medical Imaging, Angew. Chem. Int. Ed. 47, 8568-8580.

[35] Aime, S., Cabella, C., Colombatto, S., Geninatti Crich, S., Gianolio, E., and Maggioni, F. (2002) Insights into the use of paramagnetic Gd(III) complexes in MR-molecular imaging investigations, J. Mag. Reson. Imaging 16, 394-406. 
[36] Li, G., Slansky, A., Dobhal, M. P., Goswami, L. N., Graham, A., Chen, Y., Kanter, P., Alberico, R. A., Spernyak, J., Morgan, J., Mazurchuk, R., Oseroff, A., Grossman, Z., and Pandey, R. K. (2005) Chlorophyll-a Analogues Conjugated with AminobenzylDTPA as Potential Bifunctional Agents for Magnetic Resonance Imaging and Photodynamic Therapy, Bioconjugate Chem. 16, 32-42.

[37] Goswami, L. N., White, W. H., Spernyak, J. A., Ethirajan, M., Chen, Y., Missert, J. R., Morgan, J., Mazurchuk, R., and Pandey, R. K. (2010) Synthesis of Tumor-Avid Photosensitizer-Gd(III)DTPA Conjugates: Impact of the Number of Gadolinium Units in T1/T2 Relaxivity, Intracellular localization, and Photosensitizing Efficacy, Bioconjugate Chem. 21, 816-827.

[38] Spernyak, J. A., White, W. H., Ethirajan, M., Patel, N. J., Goswami, L., Chen, Y., Turowski, S., Missert, J. R., Batt, C., Mazurchuk, R., and Pandey, R. K. (2010) Hexylether Derivative of Pyropheophorbide-a (HPPH) on Conjugating with 3 Gadolinium(III) Aminobenzyldiethylenetriaminepentaacetic Acid Shows Potential for in Vivo Tumor Imaging (MR, Fluorescence) and Photodynamic Therapy, Bioconjugate Chem. 21, 828-835.

[39] Song, Y., Zong, H., Trivedi, E. R., Vesper, B. J., Waters, E. A., Barrett, A. G. M., Radosevich, J. A., Hoffman, B. M., and Meade, T. J. (2010) Synthesis and Characterization of New Porphyrazine-Gd(III) Conjugates as Multimodal MR Contrast Agents, Bioconjugate Chem. 21, 2267-2275.

[40] Luo, J., Chen, L.-F., Hu, P., and Chen, Z.-N. (2014) Tetranuclear Gadolinium(III) Porphyrin Complex as a Theranostic Agent for Multimodal Imaging and Photodynamic Therapy, Inorg. Chem. 53, 4184-4191.

[41] Aydın Tekdaş, D., Garifullin, R., Şentürk, B., Zorlu, Y., Gundogdu, U., Atalar, E., Tekinay, A. B., Chernonosov, A. A., Yerli, Y., Dumoulin, F., Guler, M. O., Ahsen, V., and Gürek, A. G. (2014) Design of a Gd-DOTA-Phthalocyanine Conjugate Combining MRI Contrast Imaging and Photosensitization Properties as a Potential Molecular Theranostic, Photochem. Photobiol. 90, 1376-1386.

[42] Ur-Rashid, H., Umar, M. N., Khan, K., Anjum, M. N., and Yaseen, M. (2014) Synthesis and relaxivity measurements of porphyrin-based magnetic resonance imaging (MRI) contrast agents, J. Struct. Chem. 55, 910-915.

[43] Ke, X.-S., Tang, J., Yang, Z.-S., and Zhang, J.-L. (2014) $\beta$-conjugation of gadolinium(III) DOTA complexes to zinc(II) porpholactol as potential multimodal imaging contrast agents, J. Porphyr. Phthalocyanines 18, 950-959.

[44] Yuzhakova, D. V., Lermontova, S. A., Grigoryev, I. S., Muravieva, M. S., Gavrina, A. I., Shirmanova, M. V., Balalaeva, I. V., Klapshina, L. G., and Zagaynova, E. V. (2017) In vivo multimodal tumor imaging and photodynamic therapy with novel theranostic agents based on the porphyrazine framework-chelated gadolinium (III) cation, Biochim. Biophys. Acta - General Subjects 1861, 3120-3130.

[45] Wu, B., Li, X.-Q., Huang, T., Lu, S.-T., Wan, B., Liao, R.-F., Li, Y.-S., Baidya, A., Long, Q.-Y., and Xu, H.-B. (2017) MRI-guided tumor chemo-photodynamic therapy with Gd/Pt bifunctionalized porphyrin, Biomater Sci. 5, 1746-1750.

[46] Lacerda, S., and Tjth, P. (2017) Lanthanide Complexes in Molecular Magnetic Resonance Imaging and Theranostics, ChemMedChem 12, 883-894.

[47] Calvete, M. J. F., Pinto, S. M. A., Pereira, M. M., and Geraldes, C. F. G. C. (2017) Metal coordinated pyrrole-based macrocycles as contrast agents for magnetic resonance imaging technologies: Synthesis and applications, Coord. Chem. Rev. 333, 82-107.

[48] Sour, A., Jenni, S., Ortí-Suárez, A., Schmitt, J., Heitz, V., Bolze, F., Loureiro de Sousa, P., Po, C., Bonnet, C. S., Pallier, A., Tóth, É., and Ventura, B. (2016) Four Gadolinium(III) Complexes Appended to a Porphyrin: A Water-Soluble Molecular 
Theranostic Agent with Remarkable Relaxivity Suited for MRI Tracking of the Photosensitizer, Inorg. Chem. 55, 4545-4554.

[49] Schmitt, J., Heitz, V., Sour, A., Bolze, F., Kessler, P., Flamigni, L., Ventura, B., Bonnet, C. S., and Tóth, É. (2016) A Theranostic Agent Combining a Two-Photon-Absorbing Photosensitizer for Photodynamic Therapy and a Gadolinium(III) Complex for MRI Detection, Chem. Eur. J. 22, 2775-2786.

[50] Kuimova, M. K., Collins, H. A., Balaz, M., Dahlstedt, E., Levitt, J. A., Sergent, N., Suhling, K., Drobizhev, M., Makarov, N. S., Rebane, A., Anderson, H. L., and Phillips, D. (2009) Photophysical properties and intracellular imaging of water-soluble porphyrin dimers for two-photon excited photodynamic therapy, Org. Biomol. Chem. 7, 889-896.

[51] Dahlstedt, E., Collins, H. A., Balaz, M., Kuimova, M. K., Khurana, M., Wilson, B. C., Phillips, D., and Anderson, H. L. (2009) One- and two-photon activated phototoxicity of conjugated porphyrin dimers with high two-photon absorption cross sections, Org. Biomol. Chem. 7, 897-904.

[52] Schmitt, J., Heitz, V., Jenni, S., Sour, A., Bolze, F., and Ventura, B. (2017) $\pi$-extended porphyrin dimers as efficient nearinfrared emitters and two-photon absorbers, Supramol. Chem. 11, 769-775.

[53] Balaz, M., Collins, H. A., Dahlstedt, E., and Anderson, H. L. (2009) Synthesis of hydrophilic conjugated porphyrin dimers for one-photon and two-photon photodynamic therapy at NIR wavelengths, Org. Biomol. Chem. 7, 874-888.

[54] Odani, T., Okada, S., Kabuto, C., Kimura, T., Shimada, S., Matsuda, H., Oikawa, H., Matsumoto, A., and Nakanishi, H. (2009) Solid-State Reactions of Crystals Containing Two Kinds of Polymerizable Moieties of Diene and Diyne, Cryst. Growth Des. 9, 34813487.

[55] Henig, J., Tóth, E., Engelmann, J., Gottschalk, S., and Mayer, H. A. (2010) Macrocyclic Gd3+ Chelates Attached to a Silsesquioxane Core as Potential Magnetic Resonance Imaging Contrast Agents: Synthesis, Physicochemical Characterization, and Stability Studies, Inorg. Chem. 49, 6124-6138.

[56] Powell, D. H., Dhubhghaill, O. M. N., Pubanz, D., Helm, L., Lebedev, Y. S., Schlaepfer, W., and Merbach, A. E. (1996) Structural and Dynamic Parameters Obtained from 170 NMR, EPR, and NMRD Studies of Monomeric and Dimeric Gd3+ Complexes of Interest in Magnetic Resonance Imaging: An Integrated and Theoretically SelfConsistent Approach1, J. Am. Chem. Soc. 118, 9333-9346.

[57] Tóth, É., Helm, L., Kellar, K. E., and Merbach, A. E. (1999) Gd(DTPA-bisamide)alkyl Copolymers: A Hint for the Formation of MRI Contrast Agents with Very High Relaxivity, Chem. Eur. J. 5, 1202-1211.

[58] Livramento, J. B., Sour, A., Borel, A., Merbach, A. E., and Tóth, É. (2006) A StarburstShaped Heterometallic Compound Incorporating Six Densely Packed Gd3+ Ions, Chem. Eur. J. 12, 989-1003.

[59] Schmitt, J., Heitz, V., Sour, A., Bolze, F., Ftouni, H., Nicoud, J.-F., Flamigni, L., and Ventura, B. (2015) Diketopyrrolopyrrole-Porphyrin Conjugates with High Two-Photon Absorption and Singlet Oxygen Generation for Two-Photon Photodynamic Therapy, Angew. Chem. Int. Ed. 54, 169-173.

[60] Piet, J. J., Taylor, P. N., Wegewijs, B. R., Anderson, H. L., Osuka, A., and Warman, J. M. (2001) Photoexcitations of Covalently Bridged Zinc Porphyrin Oligomers: Frenkel versus Wannier-Mott Type Excitons, J. Phys. Chem. B 105, 97-104.

[61] Tanaka, T., and Osuka, A. (2015) Conjugated porphyrin arrays: synthesis, properties and applications for functional materials, Chem. Soc. Rev. 44, 943-969.

[62] Susumu, K., Duncan, T. V., and Therien, M. J. (2005) Potentiometric, Electronic Structural, and Ground- and Excited-State Optical Properties of Conjugated 
Bis[(Porphinato)zinc(II)] Compounds Featuring Proquinoidal Spacer Units, J. Am. Chem. Soc. 127, 5186-5195.

[63] Hayek, A., Bolze, F., Bourgogne, C., Baldeck, P. L., Didier, P., Arntz, Y., Mély, Y., and Nicoud, J.-F. (2009) Boron Containing Two-Photon Absorbing Chromophores. 2. Fine Tuning of the One- and Two-Photon Photophysical Properties of Pyrazabole Based Fluorescent Bioprobes, Inorg. Chem. 48, 9112-9119.

[64] Drobizhev, M., Stepanenko, Y., Dzenis, Y., Karotki, A., Rebane, A., Taylor, P. N., and Anderson, H. L. (2005) Extremely Strong Near-IR Two-Photon Absorption in Conjugated Porphyrin Dimers: Quantitative Description with Three-Essential-States Model, J. Phys. Chem. B 109, 7223-7236.

[65] Nyarko, E., Hara, T., Grab, D. J., Habib, A., Kim, Y., Nikolskaia, O., Fukuma, T., and Tabata, M. (2004) In vitro toxicity of palladium(II) and gold(III) porphyrins and their aqueous metal ion counterparts on Trypanosoma brucei brucei growth, Chem. Biol. Interact. 148, 19-25.

[66] James, D. A., Arnold, D. P., and Parsons, P. G. (1994) Potency and selective toxicity of tetra(hydroxyphenyl)- and tetrakis(dihydroxyphenyl)porphyrins in human melanoma cells, with and without exposure to red light, Photochem. Photobiol. 59, 441-447.

[67] Yerly, F. (1999), in VISUALISEUR 2.3.5, OPTIMISEUR 2.3.5, Lausanne, Switzerland.

[68] Seybold, P. G., and Gouterman, M. (1969) Porphyrins XIII: Fluorescence Spectra and Quantum Yields, J. Mol. Spectrosc. 31, 1-13.

[69] Seotsanyana-Mokhosi, I., Kuznetsova, N., and Nyokong, T. (2001) Photochemical studies of tetra-2,3-pyridinoporphyrazines, J. Photochem. Photobiol. A 140, 215-222.

[70] Ogunsipe, A., Chen, J.-Y., and Nyokong, T. (2004) Photophysical and photochemical studies of zinc(ii) phthalocyanine derivatives-effects of substituents and solvents, New J. Chem. 28, 822-827.

[71] Hoebeke, M., and Damoiseau, X. (2002) Determination of the singlet oxygen quantum yield of bacteriochlorin a: a comparative study in phosphate buffer and aqueous dispersion of dimiristoyl-1-[small alpha]-phosphatidylcholine liposomes, Photochem. Photobiol. Sci. 1, 283-287.

[72] Redmond, R. W., and Gamlin, J. N. (1999) A Compilation of Singlet Oxygen Yields from Biologically Relevant Molecules, Photochem. Photobiol. 70, 391-475.

[73] Makarov, N. S., Drobizhev, M., and Rebane, A. (2008) Two-photon absorption standards in the 550-1600 nm excitation wavelength range, Opt. Express 16, 4029-4047. 